\title{
Hubert Szczęśniak
}

\section{Muzykalia w zbiorach Państwowego Muzeum Auschwitz-Birkenau' ${ }^{1}$}

\author{
Nie jest to bowiem książka o muzyce. \\ Jest to książka o muzyce w hitlerowskim \\ obozie koncentracyjnym. Można by również rzec: \\ o muzyce w krzywym zwierciadle [...]
}

$\left(\right.$ Szymon Laks) ${ }^{2}$

Dzieła i instrumenty muzyczne wykorzystywane przez kapele więźniarskie KL Auschwitz-Birkenau ${ }^{3}$, zgromadzone w Dziale Zbiorów

1 Niniejszy artykuł jest opracowaniem ostatniego rozdziału pracy licencjackiej pt. Nieznane oblicza muzyki. Muzyka w KL Auschwitz na przykładzie działalności kapel więźniarskich, napisanej pod kierunkiem dra Wojciecha Marchwicy i obronionej przez autora w lipcu 2016 roku w Instytucie Muzykologii UJ. Wcześniejsze dwa rozdziały pracy podejmują zagadnienia stanu badań nad muzyką w KL Auschwitz-Birkenau oraz roli kapel w obozowej rzeczywistości, w tym funkcji, jakie w niej pełniła muzyka.

2 Sz. Laks, Gry oświęcimskie, Oświęcim 1998, s. 11. Słowa te otwierają obozowe wspomnienia kompozytora, dyrygenta kapeli męskiej w Birkenau i powinny towarzyszyć czytelnikom poniższego tekstu.

3 Obóz przez cały okres istnienia był systematycznie rozbudowywany, w rezultacie czego obejmował trzy zasadnicze części: tzw. obóz macierzysty (od 1943 r. zwany Auschwitz I), Birkenau (Auschwitz II) oraz Monowitz (Auschwitz III) wraz z kilkudziesięcioma podobozami. Zob. m.in.: D. Czech, Kalendarz wydarzeń w KL Auschwitz, Oświęcim 1992; Auschwitz. Nazistowski obóz śmierci, red. F. Piper, T. Świebocka, Oświęcim 2004; Auschwitz 1940-1945. Węzłowe zagadnienia $z$ dziejów obozu, red. W. Długoborski, F. Piper, Oświęcim 1995; P. Setkiewicz, Z dziejów 
Państwowego Muzeum Auschwitz-Birkenau ${ }^{4}$, nie doczekały się dotąd całościowego opracowania. Jacek Lachendro ${ }^{5}$ podjął się wszakże próby rekonstrukcji repertuaru wykonywanego przez kapele oświęcimskie, oparł się jednak w dużej mierze na wspomnieniach spisanych przez byłych więźniów. Te natomiast obarczone są prawdopodobieństwem mieszania repertuaru z różnych hitlerowskich obozów koncentracyjnych, jako że wielu więźniów-muzyków po ewakuacji obozu Auschwitz-Birkenau zostało przeniesionych do innych obozów, w których także wykonywali muzykę. Biorąc pod uwagę zawodność ludzkiej pamięci, szczególnie gdy chodzi o sytuacje skrajnie traumatyczne, należy podchodzić do ich relacji z ostrożnością. Ponadto w owych relacjach najmniej uwagi poświęcono właśnie repertuarowi, więcej natomiast - roli kapeli w obozowej rzeczywistości i wpływowi granej tam muzyki na więźniów, ale także oprawców.

Przystępując do gruntownego badania działalności muzycznej w hitlerowskich obozach koncentracyjnych, należałoby zacząć od tego, co namacalnie pozostało po działalności kapel, w miarę możliwości konfrontując tego typu dane $\mathrm{z}$ informacjami podawanymi w relacjach ocalonych z Holocaustu. Przynajmniej częściowe wypełnienie tego zadania jest celem niniejszego artykułu. Autor ograniczył się przy tym do przedstawienia nieopisanych dotąd źródeł, w kwestii historii kapel oświęcimskich odsyłając do rzetelnej i aktualnej literatury przedmiotu 6 .

obozów IG Farben Werk Auschwitz 1941-1945, Oświęcim 2006; tenże, Krematoria i komory gazowe Auschwitz, Oświęcim 2010.

Oprócz kapeli męskiej działającej w obozie macierzystym (Auschwitz I) można wymienić kapele grające w podobozach: męską w Birkenau (Auschwitz II), żeńską w Birkenau, męską w Monowitz (Auschwitz III) oraz wiele pomniejszych zespołów wykonujących muzykę. Zob. J. Lachendro, Orkiestry w KL Auschwitz, „Zeszyty Oświęcimskie" 27 (2012).

4 W dalszej części artykułu autor posługuje się w odniesieniu do Państwowego Muzeum Auschwitz-Birkenau skrótem PMA-B.

5 J. Lachendro, dz. cyt., s. 9.

6 Historia kapel w KL Auschwitz-Birkenau została znakomicie opracowana przez Jacka Lachendro. Zob. tamże, passim. 


\section{llość zachowanego materiału i jego pochodzenie}

W Dziale Zbiorów PMA-B znajduje się 229 sygnatur przypisanych obiektom związanym $\mathrm{z}$ działalnością oświęcimskich kapel7. Pierwsza ich grupa to instrumenty i akcesoria muzyczne, $\mathrm{z}$ których zachowały się tylko: klarnet B, tuba basowa, akordeon oraz skrzypce, a także jeden metalowy pulpit nutowy. Istotnymi źródłami w badaniu twórczości muzycznej w niemieckich obozach koncentracyjnych są - nielicznie zachowane w zbiorach PMA-B - oryginalne dzieła skomponowane w czasie działalności Auschwitz przez więźniów-muzyków. Pozostałe obiekty tam zgromadzone to druki muzyczne wydane w Niemczech i Austrii w pierwszych trzech dekadach XX wieku, a także sporządzone na ich podstawie przez więźniów-kopistów nut rękopiśmienne odpisy głosów. Wśród omawianych muzykaliów znajduje się również kilka utworów muzycznych (rękopisów i druków) powstałych po wojnie, przesłanych przez ich twórców, a byłych więźniów, do oświęcimskiego muzeum.

Po posortowaniu materiału nutowego udało się skompletować około 200 zachowanych dzieł - druków i rękopisów. O ich proweniencji świadczy przede wszystkim trzyrzędowa pieczęć kapeli, przybijana na przysyłane do obozu partytury (il. 1).

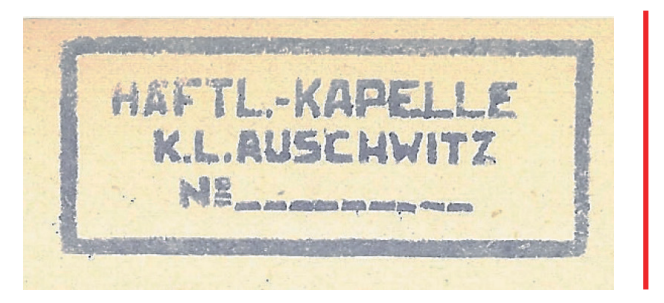

Ilustracja 1. Trzyrzędowa pieczęć obozowej kapeli.

7 Tamże, s. 9, przyp. 6. Jacek Lachendro podaje, że muzykalia zachowane w Dziale Zbiorów PMA-B zajmują przedział archiwistyczny, obejmujący sygnatury od PMO-II-4-18o do PMO-II-4-63o/24. Jednak nie wszystkie sygnatury z przytoczonego przedziału są związane z działalnością kapel oświęcimskich. Pomiędzy nimi znaleźć można różnego rodzaju sprzęt poobozowy niezwiązany z ich działalnością. Ponadto w przypadku wielu muzykaliów, a szczególnie nut (zarówno druków, jak i kopiowanych ręcznie głosów), pod jedną sygnaturą zgromadzono kilka różnych dzieł, co podyktowane było kolejnością spływania obiektów do zbiorów PMA-B w okresie powojennym.

8 Źródło: Zbiory PMA-B. 
Rubryka „No $\mathrm{N}_{\text {_ }} \ldots$ __ " umieszczona w ostatnim rzędzie ani razu nie została wypełniona. Numer porządkowy był natomiast nanoszony na tekturowe teczki, w których przechowywano nuty. Autor niniejszego artykułu nie spotkał się w żadnej relacji z informacją na temat pochodzenia owej pieczęci, co utrudnia rozstrzygnięcie, czy inicjatywa jej stworzenia należała do władz obozowych czy też do samych muzyków. Biorąc jednak pod uwagę wspomniany fakt, iż inwentaryzacji nut wykorzystywanych w czasie istnienia obozu więźniowie dokonywali przez umieszczenie numeru na teczkach, przekonująca wydaje się hipoteza, że pieczęć była wymysłem oprawców - prawdopodobnie nazistowskiej machiny administracyjnej.

Na każdej teczce widnieje tytuł lub dwa tytuły utworów muzycznych, co świadczy o tym, że teczki były kilkakrotnie używane ${ }^{9}$. Można wyróżnić dwa ich rodzaje, co stanowi dodatkową pomoc przy określaniu pochodzenia źródeł nieposiadających wyżej opisanej pieczęci. Pierwszy typ to teczki granatowe (zachowanych ok. 78) z płóciennym grzbietem i ozdobną kwadratową naklejką pośrodku (il. 2). Na naklejce

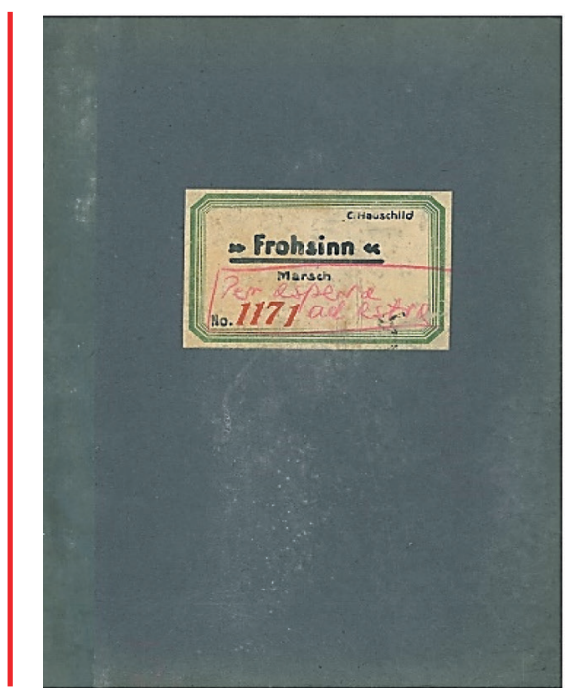

Ilustracja 2. Granatowa teczka do przechowywania nut. Na naklejce tytułowej odręczna łacińska sekwencja Per aspera ad astra („Przez trudy do gwiazd”), będąca równocześnie tytułem jednego z zachowanych utworów ${ }^{10}$.

9 Bardzo prawdopodobne jest, że w jednej teczce składane były po dwa dzieła lub więcej dzieł. Świadczą o tym tytuły napisane na awersie i rewersie niektórych teczek.

10 Źródło: Zbiory PMA-B. 
w ramce umieszczony jest tytuł, starannie, kaligraficznie zapisany czarnym tuszem i podkreślony; często pojawia się również określenie gatunku dzieła oraz podtytuł. Nazwisko autora napisane jest w ten sam sposób w prawym górnym rogu. W lewym dolnym rogu znajduje się numer napisany czerwonym atramentem, powtórzony na grzbiecie teczki.

Drugi rodzaj to zielone tekturowe teczki (zachowanych ok. 58) $\mathrm{z}$ umieszczonym pośrodku odręcznym tytułem i określeniem rodzaju kompozycji, które wpisywano czarnym tuszem (il. 3). W prawym górnym rogu znajdowało się nazwisko kompozytora, $\mathrm{w}$ lewym dolnym - numer inwentarzowy, pisany czerwonym atramentem. W większości zielonych teczek na trzeciej stronie zaginanej okładki wklejony był formularz zamówienia wydawniczego ${ }^{11}$, w niektórych wypadkach wypełniony, obejmujący informacje o kompozytorze, tytule oraz głosach orkiestrowych

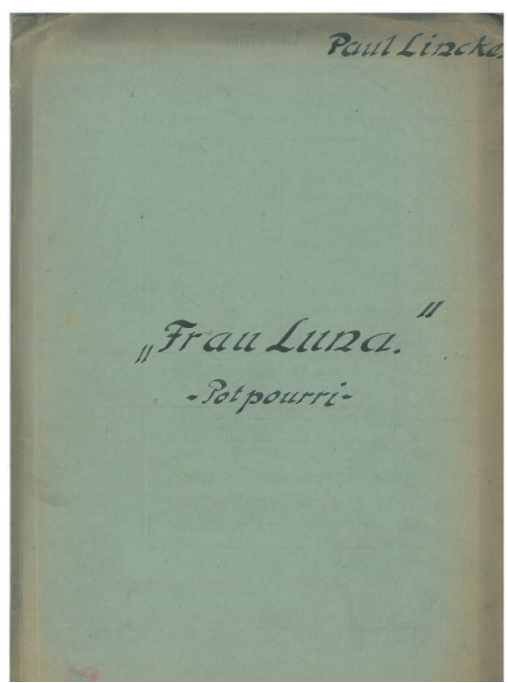

Ilustracja 3. Zielona teczka do przechowywania nut ${ }^{12}$.

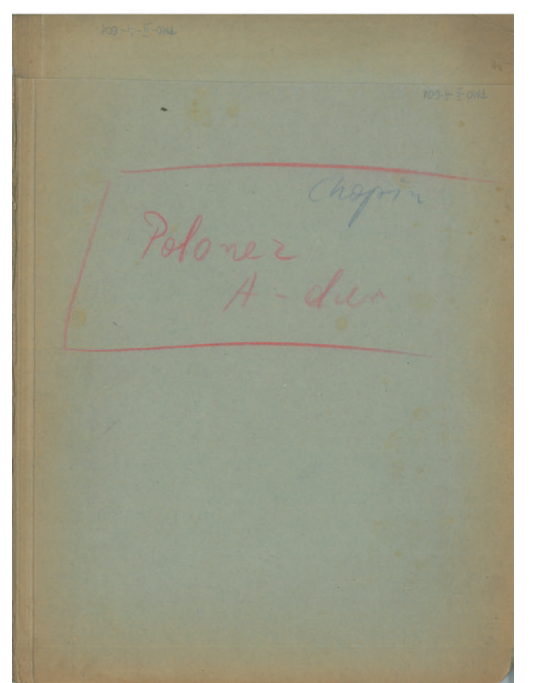

Ilustracja 4. Wewnętrzna strona zielonej teczki z odręcznym tytułem pisanym czerwoną kredką oraz, powyżej, nazwiskiem kompozytora kreślonym ołówkiem: "Chopin / Polonez / A-dur"13.

11 Wspominane zamówienia wydawnicze wklejone są wyłącznie w zielone teczki.

12 Źródło: Zbiory PMA-B

$13 \mathrm{Jw}$. 
zpustymi wierszamipoprawej stronienawpisanieichliczby (wodpowiednich rubrykach tabeli). Prawdopodobnie ten rodzaj teczek pochodzi z firmy, która realizowała zamówienia wydawnicze dla kapeli w obozie macierzystym ${ }^{14}$.

Większa część omawianego materiału źródłowego pochodzi z okresu działalności kapel w obozach KL Auschwitz-Birkenau (1941-1945). Ogromnych trudności przysparza próba powiązania zachowanego materiału nutowego z działalnością konkretnej kapeli. Jacek Lachendro twierdzi, iż materiał znajdujący się w Dziale Zbiorów PMA-B wykorzystywany zostawał tylko i wyłącznie przez orkiestrę obozu macierzystego. Zapewne była to jedyna w oświęcimskich obozach „orkiestra” (tym określeniem posługuje się badacz) ${ }^{15} \mathrm{o}$ obsadzie dostatecznie dużej, by mogła pozwolić sobie na stosunkowo wierne wykonanie dzieł przechowywanych obecnie w zbiorach PMA-B. Jednakże nie mamy pewności, czy nuty te nie były wykorzystywane, aranżowane, przepisywane i udostępniane pozostałym kapelom ${ }^{16}$.

Warto wspomnieć, że po wojnie obozowe nuty przebyły długą drogę, zanim trafiły do zbiorów oświęcimskiego Muzeum. Po ewakuacji więźniów nie pozostały, jak można by przypuszczać, na terenie tworzonego później Muzeum w Oświęcimiu, lecz, podobnie jak pozostałe mienie pohitlerowskie, przeszły w mało znanych okolicznościach w ręce osób trzecich. Okoliczności te przybliża nieco relacja Wiktora Zielińskiego ${ }^{17}$, byłego pracownika Milicji Obywatelskiej, który zabezpieczał poobozowe mienie, przekazywane przez wycofującą się z Polski armię radziecką. Autor relacji stwierdza, że o protokolarnym przekazaniu pozostałych rzeczy nie mogło być mowy - zapewne nie tylko z powodu olbrzymiej liczby pozostawionych po działalności obozu przedmiotów, lecz także

14 Jacek Lachendro przytacza relację Henryka Króla (Archiwum PMA-B, Zespół Oświadczenia, t. 76, k. 204-205), który twierdzi, że partytury zostały przesłane do obozu z wydawnictwa Breitkopf und Härtel w Lipsku (Zob. J. Lachendro, dz. cyt., s. 32). Trudno tę informację potwierdzić. Badania zachowanych muzykaliów pokazują, iż w użyciu były partytury wielu niemieckich i włoskich wydawnictw muzycznych (zob. Aneks III).

15 Zespół wykonawczy w obozie macierzystym jako jedyny z powstałych w kompleksie obozów Auschwitz-Birkenau można zgodnie z nomenklaturą muzyczną nazwać orkiestrą (względnie stały skład osiemdziesięcioosobowy). Pozostałe zespoły winno rozpatrywać się, używając bardziej odpowiedniego, gdyż uwzględniającego zarówno płynność obsady, jak i użytkowość funkcji, określenia kapela więźniarska (Häftlingskapelle) lub - żargonowo - lagerkapela.

17 Archiwum PMA-B, Zespół Oświadczenia, t. 84, k. 112-116. 
ze względu na ówczesną sytuację polityczną. Zieliński kwituje także to, co wielokrotnie widział, przebywając na obozowym terenie podczas okupowania go po wojnie przez radzieckie wojsko:

[...] Jeśli idzie o mienie zrabowane, które $\mathrm{w}$ drobnych resztkach posiada i eksponuje Państwowe Muzeum w Oświęcimiu, to jest to niewątpliwie resztka tego, co widziałem w składach - budynkach dzisiejszej kolonii im. Leni$\mathrm{na}^{18} \mathrm{i}$ to, co bezładnie walało się na terenie przyobozowym $[\ldots]^{19}$

O losie przedmiotów pozostałych po hitlerowskim obozie, w tym także nut i instrumentów, świadczą dalsze słowa relacjonującego:

[...] Nie umiem wyjaśnić, czy w domach opuszczonych przez Niemców były jakieś obrazy, rzeźby czy inne przedmioty wykonane rękami więźniów. Nie wykluczam jednak takiej możliwości. Na całym rozległym terenie byłego obozu walały się resztki mienia poobozowego, stąd tu i tam spotkać można było pasiak więźniarski, jakąś część munduru niemieckiego, narzędzia pracy, czy książki i papiery. Osobiście tymi sprawami nie interesowałem się. Gdy jednak natrafiłem na nuty różnych utworów to je zabrałem, ale miało to miejsce kilka lat po wojnie. Te nuty, obrazek - oleodruk, który podarował mi oficer radziecki, kartkę z receptariusza jednego z lekarzy niemieckich stawiam do dyspozycji Państwowego Muzeum w Oświęcimiu [... $]^{20}$

Istnieje domniemanie, że nut użytkowanych w obozie Auschwitz-Birkenau było znacznie więcej, niż by wynikało z obecnego stanu zachowania. Z relacji więźniów-muzyków wiadomo, iż zabierali oni ze sobą instrumenty podczas ewakuacji obozu. Podobnie mogło być z drukami, bądź co bądź przedstawiającymi pewną wartość rynkową. Niezachowanie się zapisów marszów i podobnej muzyki wykonywanej przez orkiestry dęte można prawdopodobnie tłumaczyć tym, iż nuty pozostałe po kapelach więźniarskich wykorzystywane były następnie przez orkiestry armii radzieckiej, stacjonujące w oświęcimskich obozach po wojnie. Nie można wykluczyć także lokalnego wykorzystywania nut przez okoliczne orkiestry dęte (w tym górnicze), biorąc

18 Dziś osiedle rtm. Witolda Pileckiego. Nazwa zmieniona w 1991 roku z inicjatywy historyka Adama Cyry.

19 Archiwum PMA-B, Zespół Oświadczenia, t. 84, k. 115-116.

20 Tamże, k. 115. 
pod uwagę mnogość takich zespołów wykonawczych w Oświęcimiu i okolicach oraz opisywaną przez Zielińskiego niedbałość przy zabezpieczaniu ogromu porzuconego mienia poobozowego.

Pierwsze przekazane Muzeum w Oświęcimiu nuty datowane są na 1963 rok. Dalszy materiał nutowy oraz instrumenty przekazywano następnie w wielu etapach. W latach: 1963, 1967, 1971, 1973, 1975, 1983, 1989, 1993, 1995, 1997 zebrano pierwszą grupę zachowanego materiału, zawierającą 85 obiektów. Druga, liczniejsza, zawierająca 144 obiekty, została zakupiona w latach 2005 oraz 2006 przez Muzeum Auschwitz-Birkenau. Partytury przekazywane były do Działu Zbiorów PMA-B wraz z oryginalnymi teczkami, lecz ich zawartość została przemieszana ${ }^{21}$. Podczas archiwizacji poszczególne jednostki pozostawiono w układzie, w jakim zostały dostarczone. Stąd wynika ogromna trudność badań: odtworzenie repertuaru zakłada konieczność uporządkowania zasobów oraz wyodrębnienia wszystkich tytułów dzieł i nazwisk kompozytorów - nie tylko widniejących na samych drukach i rękopisach, lecz także zapisanych na teczkach i formularzach zamówień wydawniczych, a nieobecnych w zachowanym zasobie. Dopiero uwzględnienie tych wszystkich informacji daje przybliżony obraz zbioru muzycznego, jaki był w posiadaniu kapel w KL Auschwitz-Birkenau (patrz: Aneks I).

\section{Zachowane instrumenty muzyczne}

Liczba zachowanych instrumentów muzycznych użytkowanych przez kapele więźniarskie w Auschwitz-Birkenau jest bardzo mała, zwłaszcza w porównaniu do zachowanych w znacznie większej ilości dzieł plastycznych ${ }^{22}$. Biorąc pod uwagę liczbę wykonawców samej tylko orkiestry

21 Ów „archiwistyczny chaos” nie wynika oczywiście z winy Muzeum, co należy stanowczo podkreślić. Autor wątpi również, że mógł powstać poprzez osoby, które przechowywały cenne historycznie muzykalia po wojnie, zanim te trafiły do zbiorów. Nieład mógł być wynikiem pospiesznego zabezpieczania poobozowego mienia i prawdopodobnie bardzo delikatnego obchodzenia się z nim po wojnie. Autor szczerze wierzy, iż wówczas nie uporządkowano materiału nutowego tylko z obawy przed jego uszkodzeniem.

22 Zob. szerzej: J. Kupiec, Cóż po nas zostanie...? Życie i twórczość więźnia obozu Auschwitz Mieczysława Kościelniaka, Oświęcim 2003; A. Sieradzka, Pozostawić po sobie ślad. Lekcja internetowa o sztuce w KL Auschwitz, Oświęcim 2016, [online] http://lekcja.auschwitz.org/pl_18_sztuka/ [dostęp: 20.10.2016] (tamże: bibliografia dotycząca zagadnienia dzieł plastycznych w KL Auschwitz). 
w obozie macierzystym, wynoszącą w szczytowym okresie funkcjonowania ok. 100 osób, cztery zachowane instrumenty ${ }^{23}$ - wszystkie przesłane do Działu Zbiorów po wojnie - wydają się ledwie namiastką instrumentarium kapel w KL Auschwitz-Birkenau. Wysoki numer inwentarzowy zachowanej trąby - „basy Beiny 158” (wybity na doczepionej do niej blaszce) - uświadamia, jak wiele instrumentów wykorzystywano. Wiadomo, że większość instrumentów należała do muzyków - były im przesyłane do obozu przez rodziny ${ }^{24}$ (przynajmniej na początku działalności kapel); rzadziej dostarczały ich władze obozu. Zagadką pozostają dzieje dwóch fortepianów, na których w okresie funkcjonowania obozu grali Adam Kopyciński i Teodor Liese ${ }^{25}$ (jeden z tych instrumentów został wyłowiony z rzeki Soły), jak również fortepianu należącego do kapeli żeńskiej w Birkenau ${ }^{26}$. Nie wiadomo także nic o pulpitach nutowych, przejętych, jak pisał Szymon Laks, przez męską lagerkapelę w Birkenau po zgładzeniu muzyków przybyłych $z$ Theresienstadt ${ }^{27}$. Pulpity widać chociażby na fotografiach kapeli w obozie macierzystym (il. 5). Zachował się tylko jeden pulpit metalowy; drewniane pulpity mogły zostać użyte jako opał lub ulec niszczącemu wpływowi czasu.

23 Szczegółowy opis zachowanych instrumentów znajduje się w Aneksie I.

24 Zob. szerzej: Archiwum PMA-B, Zespół Oświadczenia, t. 96, k. 16-21, relacja Franciszka Stryja; tamże, t. 33, k. 59-6o, relacja Jana Baranioka; tamże, t. 73, k. 86-88, relacja Bolesława Majcherczyka.

25 Zob. I. Szczepański, Häftlingskapelle, Warszawa 1990, passim.

26 Zob. Sz. Laks dz. cyt., s. 103.

27 „[...] Od niedawna zaistniał w naszym sąsiedztwie «obóz czeski», przybyły z Theresienstadt... Mieszkają razem z żonami i dziećmi, zachowali długie włosy i dawne uczesanie, nie chodzą do żadnej roboty, są wcale dobrze karmieni. Mają nawet mały zespół muzyczny, liczący kilkanaście osób [...]. I oto pewnego dnia, jak grom z jasnego nieba spada na nas straszna nowina. [...] Rzecz zaczyna się całkiem niewinnie: od dłuższego czasu pulpity nasze, przegniłe od częstego przebywania na powietrzu i przesiąknięte wilgocią, są już prawie nie do użytku [...]. I oto następuje szatański zbieg okoliczności [...]. Po paru dniach przybiega goniec ze zleceniem, abym zgłosił się niezwłocznie do komendanta $\mathrm{z}$ kilkoma muzyka$\mathrm{mi}$, ale bez instrumentów. Udajemy się tam zaintrygowani [...]. «Słyszałem, że potrzebne wam są pulpity. Zabierajcie. Zorganizowałem specjalnie dla waszej kapeli». Poznajemy te pulpity. Pochodzą one z czeskiego obozu, który mieliśmy kiedyś okazję odwiedzić służbowo. Cztery tysiące Czechów, którym zazdrościliśmy beztroskiego dobrobytu, zostało ubiegłej nocy puszczonych z dymem. [...] Taka była cena zdobytych pulpitów [...]”. Cyt. za: Sz. Laks, dz. cyt., s. 93-94. 


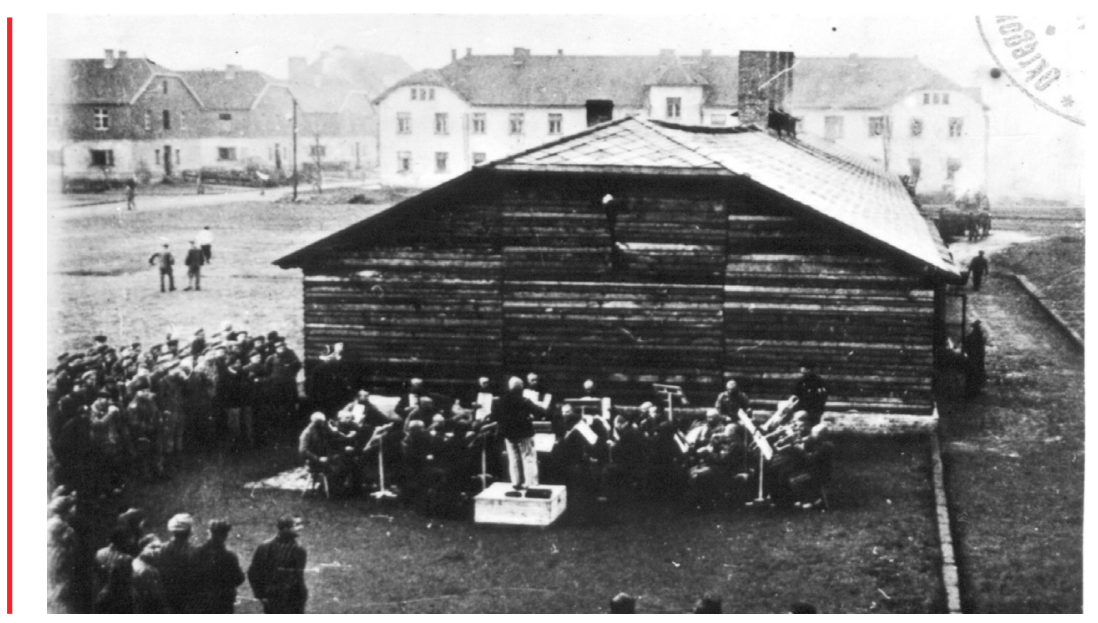

Ilustracja 5. Fotografia kapeli przed kuchnią obozową w 1942 roku²8.

28 Źródło: Archiwum PMA-B, nr neg. 337. Oryginalne zdjęcie jest bardzo słabej jakości i niewielkich rozmiarów. Poniżej zamieszczony został opis sporządzony na podstawie bardzo dużych przybliżeń.

Na pierwszym planie widoczna kapela obozu macierzystego, składająca się z około 25 muzyków. Zespół gra przed budynkiem kuchni obozowej, niedaleko bramy. Po lewej stronie niewielka grupa słuchaczy, ustawionych wokół kapeli. $\mathrm{Na}$ drugim planie po lewej stronie bloki więźniarskie, w centralnym miejscu blok nr 25 .

Kapela ustawiona jest w półkolu. W centralnym miejscu dyrygent, stojący na drewnianym podeście (mierzącym ok. $50 \mathrm{~cm}$, co oceniono względem nóżek pulpitów). Na podeście za dyrygentem widoczna teczka (z nutami?) oraz niezidentyfikowany przedmiot - najprawdopodobniej czapka dyrygenta. Po jego lewej stronie w pierwszym i drugim pulpicie siedzą skrzypkowie (ok. 5 osób), za nimi trzech akordeonistów (wyraźnie odbijająca się biała klawiatura po prawej stronie instrumentów). Pośrodku naprzeciwko dyrygenta instrumentaliści w większości trudni do zidentyfikowania, jeden grający na klarnecie, $w$ drugim pulpicie prawdopodobnie dwóch kolejnych akordeonistów. Po prawej stronie dyrygenta w pierwszym pulpicie skrzypkowie lub altowioliści (4 osoby). Za nimi pusty pulpit. Pierwszy z muzyków opiera instrument o kolano (nie gra). W drugim pulpicie po prawej stronie saksofonista, obok niego drugi muzyk, prawdopodobnie trębacz (w tym miejscu zdjęcie prześwietlone). Za nim muzyk stojący, grający na instrumencie perkusyjnym (prawdopodobnie werblu lub innym tego rodzaju bądź jakimś rodzaju dzwonków). W trzecim, ostatnim pulpicie, dwoje trębaczy oraz dwoje puzonistów, jeden z nich trzymający instrument skierowany w górę (nie gra). Za nimi jeszcze jedna postać, trudno stwierdzić, czy na czymś gra.

Na zdjęciu możliwe jest rozpoznanie około 10 drewnianych pulpitów nutowych. Więźniowie ubrani są w pasiaki (najlepiej widoczne paskowane spodnie dyrygenta). Dyrygent ubrany w ciemną marynarkę. 


\section{Klasyfikacja zachowanych nut}

Jak już wspomniano, materiały nutowe przechowywane w Dziale Zbiorów oświęcimskiego Muzeum nie zostały skatalogowane według kryteriów muzycznych, lecz jako jednostki archiwistyczne opatrzone sygnaturami zgodnie z datą i kolejnością przekazania do muzealnych zasobów. Stąd niektóre utwory występują kilkakrotnie pod różnymi sygnaturami (tj. partytura i głosy jednego dzieła rozrzucone są pomiędzy sygnaturami); zawartość teczek nie zawsze zgadza się z tytułami dzieł, jakie na nich figurują; to samo dotyczy formularzy wydawniczych. Ponadto pod jedną sygnaturą natrafić można na kilka dzieł muzycznych, niejednokrotnie różnych autorów, w jeszcze innych natomiast znajdują się rękopiśmienne kopie głosów orkiestrowych dzieł widniejących pod inną sygnaturą w postaci druku.

Pod względem obsady wykonawczej materiał jest zróżnicowany. Przeważają utwory przeznaczone na orkiestrę symfoniczną, czasem uzupełniane instrumentami charakterystycznymi dla bandu jazzowego. Ponadto zarysowuje się linia podziału pomiędzy symfonicznymi dziełami instrumentalnymi oraz wokalno-instrumentalnymi, z reguły z głosem solowym, ale także większymi zespołami wokalnymi. Nie sposób oczywiście założyć, że przy wykonywaniu utworów w obozie respektowano oryginalną postać partytur, obsady we wszystkich kapelach były bowiem zmienne ${ }^{29}$. Dzieła aranżowano według instrumentarium, którym w danej chwili dysponowano, lub też nie wykonywano wszystkich partii. Nie wiadomo, w jaki sposób korzystano z nut przeznaczonych na fortepian (np. Kolysanka Adama Kopycińskiego zachowana w rękopisie kompozytorskim, Koketterie Ericha Otto, Niagara Carla Robrechta, Slawische Rhapsodie Friedricha Wilhelma Rusta) oraz na skrzypce z towarzyszeniem fortepianu (zeszyt Stücke Alter Meister berlińskiego wydawnictwa Ad. Köster; Duety na skrzypce i fortepian op. $137 \mathrm{nr}$ 1-3 Franza Schuberta, La Principessa del Valzer Luisa Antonia Escobara) - prócz kameralistyki wykonywanej w obozowej rzeczywistości, być może służyły one jako podstawa transkrypcji na składy instrumentalne, którymi w danym momencie dysponowano.

Grupa dzieł symfonicznych to pozycje „żelaznego repertuaru”, głównie XIX-wieczne, choć zdarzają się wcześniejsze (Vivaldi, Händel, Haydn, Mozart, Beethoven, Weber, Berlioz, Grieg, Verdi, Puccini, Czajkowski,

29 Zob. szerzej: H. Dunicz-Niwińska, Drogi mojego życia. Wspomnienia skrzypaczki $z$ Birkenau, Oświęcim 2013. Autorka zwraca uwagę na ogromne zróżnicowanie obsadowe kapeli żeńskiej w Birkenau, na której czele stała Alma Rosé. 
Rimski-Korsakow i Chopin - Polonez A-dur w wersji orkiestrowej). Są to bez wyjątku utwory, które były obecne w powszechnym repertuarze kręgu niemieckojęzycznego (w Niemczech, ale także w Austrii) bezpośrednio przed wybuchem wojny. To samo dotyczy bardzo obszernej grupy dzieł muzyki popularnej. Reprezentują ją przede wszystkim fragmenty popularnych oper i operetek (zarówno klasycznych, jak i nowszych, tworzonych w dwudziestoleciu międzywojennym). Wykorzystywano wtedy uwertury do znanych oper i operetek, opracowywano znane arie i tańce, tworzono przekrojowe suity bądź modne ówcześnie potpourri. Najbardziej popularne były operetkowe „perły” Franza von Suppé, Franza Lehára, Johanna Straussa i Jacquesa Offenbacha. Ponadto w tej grupie pojawiają się nazwiska: Heinricha Berté (1857-1924) - austrowęgierskiego kompozytora, twórcy sześciu baletów oraz dwunastu operetek ${ }^{30}$, Paula Linckego (18661946) - niemieckiego kompozytora, twórcy operetek, ale także pieśni oraz marszów, właściciela wydawnictwa muzycznego Apollo Verlag, z którego pochodzi znaczna część repertuaru zachowanego w zbiorach PMA-B ${ }^{31}$, E. Künneckego, E. Meyera-Helmuda, H. Steinera, W. Lautenschlägera, J. Rixnera, G. Winklera, E. Otto, H. Heumanna, L. Siede i wielu innych.

Kolejna, największa pod względem zachowanej ilości materiału grupa to aranżacje nowoczesnej muzyki rozrywkowej (głównie znanych pieśni ludowych, np. neapolitańskiej, „szlagierów” musicalowych, muzyki tanecznej i muzyki filmowej, patrz: Aneks III). Często pojawiają się tu nazwiska: Josefa Rixnera (1902-1973) - niemieckiego kompozytora muzyki lekkiej tworzącego w Berlinie od 1932 roku $^{32}$, Hansa Ailbouta (1879-1957) - niemieckiego kompozytora muzyki filmowej oraz rozrywkowej ${ }^{33}$ oraz całkowicie nieznanych dziś twórców: Otto Stolzenwalda i Heinricha Steinera. Kompozytorów muzyki filmowej zawartej w zbiorach PMA-B bardzo trudno dziś zidentyfikować. Autorowi udało się znaleźć informacje o Franzu Grothe - twórcy muzyki do około 167 filmów,

30 A. Lamb, Berté, Heinrich [Harry], [w:] Grove Music Online, [online] http://www. oxfordmusiconline.com/subscriber/article/grove/music/02899 [dostęp: 29.06.2016].

31 Tenże, hasło: Lincke, (Carl Emil) Paul, [w:] Grove Music Online, [online] http://www. oxfordmusiconline.com/subscriber/article/grove/music/16669 [dostęp: 29.06.2016]. Informacje o kompozytorze za: Josef Rixner, [w:] Munzinger Online. Biographien, [online] https://www.munzinger.de/search/go/document.jsp?id=00000006582 [dostęp: 31.03.2017]. Informacje o kompozytorze za: Hans Ailbout, [w:] HeBu. Musikverlag GmbH, [online] https://www.munzinger.de/search/go/document.jsp?id=0oooooo6582 [dostęp: 31.03.2017]. 
lecz także aranżerze oraz twórcy niezwykle popularnych pieśni - przebojów, bliskim współpracowniku Franza Lehára, Emmericha Kálmána oraz Roberta Stolza - wpływowych osobistości niemieckiej sceny operetkowej I połowy XX wieku ${ }^{34}$, która bezpośrednio oddziaływała na późniejszy rozwój dźwiękowej ilustracji do początkowo niemych filmów.

W kontekście wyżej przedstawionej klasyfikacji należy zwrócić uwagę na ogromny udział w repertuarze muzyki użytkowej opracowań tańców, szczególnie walców, ale także polek, galopów, tang, fokstrotów, częstokroć opracowanych wokalnie. Ponadto kilka kompozycji reprezentuje modną przed wojną muzykę egzotyczną (inspiracje afrykańskie, japońskie itp.). Muzyka militarna, obejmująca tylko kilka pozycji, to przeważnie marsze.

Szczególną uwagę należy zwrócić na obecność w repertuarze kompozycji Paula Graenera - dyrygenta oraz kompozytora, działacza politycznego niemieckiej partii nazistowskiej (od 1933 roku), wiceprzewodniczącego Goebelsowskiej Reichsmusikkammer oraz następcy Richarda Straussa na prestiżowym stanowisku głównego dyrygenta w szeregach partii narodowosocjalistycznej35. Kompozytor ten, jak pisze Erik Levi ${ }^{36}$, nieposiadający własnego języka muzycznego, a jedynie naśladujący styl stworzony przez R. Straussa, H. Pfitznera oraz M. Regera, jako twórca obracał się wokół popularnej ówcześnie Zeitoper. Nazwisk kompozytorów firmujących obozowy repertuar, a cieszących się poważaniem w III Rzeszy można podać więcej: jest to oczywiście cieszący się sympatią Hitlera Richard Wagner ${ }^{37}$, twórca firmujący germański mit narodowy, a także Franz Lehár.

Pozornie zaskakujący jest fakt, że z repertuaru obozowego nie wyeliminowano dzieł kompozytorów pochodzenia żydowskiego, jak np. Antonia Vivaldiego, będącego przykładem „reprezentatywnego

34 I. Grünberg-Rinkleff, Grothe, Franz (Johannes August), [w:] Grove Music Online, [online] http://www.oxfordmusiconline.com/subscriber/article/grove/music/11836 [dostęp: 29.06.2016].

35 E. Levi, Graener, Paul, [w:] Grove Music Online, [online] http://www.oxfordmusiconline.com/subscriber/article/grove/music/11578 [dostęp: 29.06.2016].

36 Tamże.

37 Nie zachowały się żadne słowa samego Hitlera na ten temat, jednakże wielu jego współpracowników wypowiadało się w tej kwestii. Wspomniał o tym np. Hans Frank w jednej z rozmów z amerykańskim psychiatrą Leonem Goldensohnem w czasie trwania procesów norymberskich: „Nie pociąga mnie Wagner - zauważył z powagą - mam bardziej klasyczne gusty. Führer nie miał gustu, Wagner podobał mu się ze względu na pompatyczną teutońską świetność [...]”. Cyt. za: L. Goldensohn, Rozmowy norymberskie, tłum. D. Jankowska i A. Weseli-Ginter, Warszawa 2004, s. 55. 
Żyda" w pseudomuzykologicznych pracach nazistowskich teoretyków muzyki, np. Roberta Passenlehnera ${ }^{38}$. Na podstawie pobieżnej choćby kwerendy niemieckich i austriackich repertuarów koncertowych i programów radiowych nadawanych w czasie okupacji można się jednak przekonać, że wdrażanie rasistowskich dyrektyw w praktykę życia muzycznego nie było w ośrodkach zarządzanych przez III Rzeszę wszechobecnym zjawiskiem. Twórcy programów uwzględniali bowiem w pierwszym rzędzie gusty słuchaczy ${ }^{39}$, a ci zgłaszali zapotrzebowanie na muzyczne „przeboje”, wśród których również były utwory Żydów: Straussów, Mendelssohna czy właśnie Vivaldiego. To samo dotyczy produktów tzw. U-Musik (Unterhaltungsmusik, muzyki popularnej) oraz utworów jazzowych (które przez nazistów były uważane za produkt żydowski ${ }^{40}$ ). Istniało na nie w latach 30 . ogromne społeczne zapotrzebowanie, były wydawane w wielkich nakładach, co zapewne ułatwiło dostęp do nich w latach wojny. Ideolodzy nowej kultury III Rzeszy zakładali oczywiście, że „zła” kultura muzyczna powinna być zastąpioną nową (tu proponowano powrót do niemieckiej muzyki dawnej i ludowej, a także nową twórczość religijną) ${ }^{41}$. Trzeba jednak przyznać, że owa „wychowawcza” tendencja zupełnie nie objawiła się w działaniach władz obozu Auschwitz-Birkenau. Można by określić jego repertuar muzyczny jako schlebiający modzie i komercyjny, gdyby nie świadomość, że produkcje muzyczne więźniów bynajmniej nie były obliczone na zysk...

Udział najmodniejszych utworów muzyki poważnej i rozrywkowej w repertuarze obozowym sprawia, że jego przeważającą część stanowią dzieła pogodne, niejednokrotnie emanujące erotyką (w przypadku operetek), humorem i radością. W zaistniałej sytuacji - głodu, bólu, cierpienia, a niejednokrotnie „zezwierzęcenia” człowieka ${ }^{42}$ - stanowiły one

38 Zob. szerzej: A. Tuchowski, Racjonalistyczne podstawy narodowosocjalistycznej refleksji o muzyce, [w:] tenże, Nacjonalizm, szowinizm, rasizm a europejska refleksja o muzyce i twórczość kompozytorska okresu międzywojennego, Wrocław 2015, s. 42-68. Zob. P.M. Potter, Die deutscheste der Künste. Musikwissenschaft und Gesellschaft von der Weimar Republik bis zum Ende des Dritten Reichs, Stuttgart 200o, s. 51.

40 Tamże, s. 23.

41 Tamże.

42 J. Górniak, Jeszcze o muzyce w Oświęcimiu, „Ruch Muzyczny” 1946, nr 2, s. 9-12. Autor przedstawia dosyć szczegółową analizę psychologiczną więźnia, który z powodu głodu, wycieńczenia i zimna ulegał „zezwierzęceniu”, któremu zacierała się granica pomiędzy życiem a śmiercią i wręcz obsesją stawała się dla niego walka o pożywienie. Autor zwraca uwagę na rodzaj tortury, jaką stała się w tej sytuacji muzyka - zamiast wysłuchania symfonii Beethovena więźniowie woleliby cokolwiek 
przytłaczający kontrast w odniesieniu do rzeczywistości obozu śmierci $\mathrm{i}$ były przyczyną przytaczanej $\mathrm{w}$ wielu powojennych relacjach muzykofobii wśród więźniów, głównie tych nieprzejawiających większych zainteresowań kulturalnych przed zniewoleniem. „Rubaszny humor”43 emanujący $\mathrm{z}$ dzieł granych $\mathrm{w}$ obozie był także przyczyną poważnych rozterek muzyków co do moralnego znaczenia wykonawstwa muzyki w obozowej rzeczywistości - wszak niejednokrotnie ułatwiało ono władzom zarządzanie masami ludzi skatowanych ciężką pracą. Należy zatem podkreślić, że obozowi oprawcy - nieświadomie bądź świadomie - uczynili muzykę torturą także dla wykonującej ją grupy więźniów-muzyków.

\section{Twórczość powstała w KL Auschwitz-Birkenau i zachowana w rękopisach ze zbiorów PMA-B}

W zbiorach PMA-B przechowywane są dzieła, które zostały skomponowane w czasie istnienia kompleksu obozów Auschwitz-Birkenau przez więźniów. Zachowały się tylko trzy takie kompozycje. Pierwszą z nich jest Buna-Lied, napisana przez Antona Gepperta oraz Fritza Löhnera-Bedę (numer więźniarski: 68561) w KL Auschwitz III (Monowitz)

zjeść. Górniak po wojnie na łamach „Ruchu Muzycznego” polemizuje z Adamem Kopycińskim - drugim z kolei dyrygentem kapeli w obozie macierzystym, który pisał o działalności muzycznej w Auschwitz. Zob. szerzej: A. Kopyciński, Orkiestra w oświęcimskim obozie koncentracyjnym, „Przegląd Lekarski” 1964, nr 1; tenże, Ruch Muzyczny za drutami Oświęcimia, „Ruch Muzyczny” 1945, nr 5 (odpowiedź na atak Górniaka); tenże, Skład orkiestry obozowej w Oświęcimiu, „Przegląd Lekarski” 1966, nr 1; tegoż relacje w: I. Szczepański, dz. cyt., passim.

43 A. Siciński, Pieśn pomogła przetrwać. W 25. rocznicę oswobodzenia Oświęcimia, „Dziennik Ludowy” 1969, nr 22, s. 8 [kopia w:] Archiwum PMA-B, Zespół Oświadczenia, t. 72, k. 182. Dziennikarz ten w tekście o odważnym tytule Pieśń pomogła przetrwać - w 25. rocznicę oswobodzenia Oświęcimia, starał się udowodnić, jak wielką rolę stanowił ruch oporu, jakim była organizacja życia kulturalnego w oświęcimskim obozie koncentracyjnym. Skupił się na opisaniu prywatnego wieczornego muzykowania i czytania poezji przez więźniów na różnych blokach oraz opisał tak, jak pamiętał, „wielką orkiestrę obozową”. O tytułowej pieśni w artykule pojawia się mało informacji. Autor przytacza także krótki opis programów oficjalnych niedzielnych koncertów dla więźniów, odbywających się przy budynku obozowej kuchni, kwitując: „Miały one charakter składanek, w których programie było miejsce na rzewną lub sentymentalną pieśń, sztuki magiczne, sceny mimiczne i rubaszny humor...” Nie da się ukryć, iż szokuje język „ducha demokracji ludowej” i porównania użyte przez Sicińskiego w cytowanym tekście. 
4 grudnia 1942 roku. Pierwszy jest autorem muzyki do pieśni, pochodzącym z Wiednia; niestety nie zachowały się o nim jakiekolwiek inne informacje. Drugi to autor tekstu, znany pisarz oraz librecista operetkowy współpracujący z Franzem Lehárem, a także twórca tekstu do Das Buchenwaldlied skomponowanej pod koniec 1938 roku do muzyki Hermanna Leopoldiego ${ }^{44}$. Rękopis Buna-Lied, jak dotąd jedyne znane źródło tej pieśni, jest prawdopodobnie tylko odpisem. Świadczy o tym powojenna notatka służbowa spisana na odwrocie (zob. Aneks III).

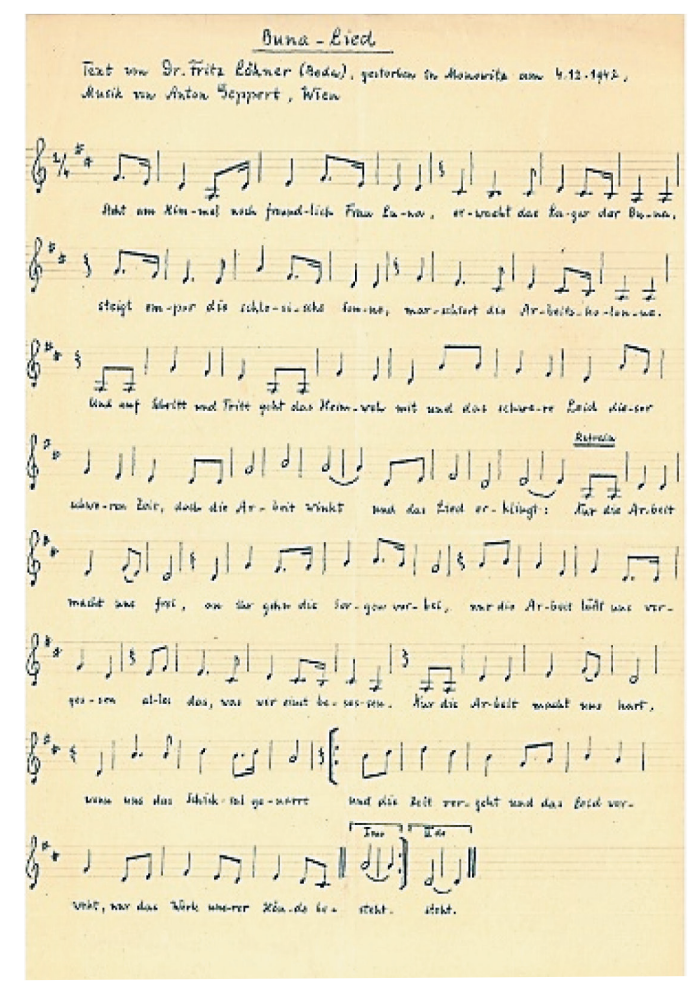

Ilustracja 6. Rękopis pieśni Buna-Lied ${ }^{45}$.

44 Informacje o pisarzu za: B. Denscher, Fritz Löhner, [w:] Lexikon verfolgter Musiker und Musikerinnen der NS-Zeit, [online] https://www.lexm.uni-hamburg.de/object /lexm_lexmperson_ooo02627 [dostęp: 31.03.2017]. Löhner wywarł ogromny wpływ na psychoanalizę Viktora Frankla i jego koncepcję logoterapii (nauki o sensie życia). Zob. V. Frankl, Człowiek w poszukiwaniu sensu, tłum. A. Wolnicka, Warszawa 2008.

Źródło: Zbiory PMA-B, sygn. PMO-II-4-456. 
Buna-Lied

Steht am Himmel noch

freundlich Frau Luna,

erwacht das Lager der Buna,

steigt empor die schlesische Sonne,

marchfest die Arbeitskolonne.

Und auf Schritt und Tritt

geht das Heimweh mit

und das schwere Leid

dieser schweren Zeit,

doch die Arbeit winkt

und das Lied erklingt:

(Ref.)

Nur die Arbeit macht uns frei,

an ihr gehn die Sorgen vorbei,

nur die Arbeit läßt uns vergessen

alles das, war wir einst besessen.

Nur die Arbeit macht uns hart,

wenn uns das Schicksal genarrt.

Und die Zeit vergeht

und das Leid verweht,

nur das Werk unserer Hände besteht.
Buna-Lied ${ }^{46}$

Stoi jeszcze na niebie

życzliwa Pani Luna,

budzi się obóz Buna,

wznosi się ku górze śląskie słońce,

maszerują kolumny robocze.

I na każdym kroku

towarzyszy tęsknota za domem

i ciężar cierpienia

tych ciężkich chwil,

jednak praca czeka

i rozbrzmiewa pieśń:

(Ref.)

Tylko praca czyni nas wolnymi,

dzięki niej mijają zmartwienia,

tylko praca pozwala nam zapomnieć

o wszystkim tym, co niegdyś posiadaliśmy

Tylko praca czyni nas twardymi,

kiedy przeznaczenie $\mathrm{z}$ nas drwi.

A czas upływa

i rozwiewa cierpienia,

tylko praca naszych rąk pozostaje.

Omawiana pieśń wykazuje bardzo duże związki z Buchenwaldlied, zarówno pod względem treści, jak i opracowania muzycznego. W jedynym znanym dotychczas źródle, czyli rękopisie złożonym w zbiorach PMA-B, widnieje pod zapisem nutowym tylko jedna zwrotka tekstu, mówiąca o tym, że wyłącznie praca daje więźniom wolność w trudnej obozowej rzeczywistości, pełnej cierpienia i zmartwień (warto zauważyć obecną w nim grę słów: Frau Luna - Frau Buna; Frau Luna to tytuł bardzo popularnej przed wojną operetki Paula Linckego, Buna natomiast to nazwa słynnego niemieckiego syntetycznego kauczuku, produkowanego od 1936 roku). Pieśń ma budowę zwrotkową $\mathrm{z}$ refrenem. W zakończeniu występują typowe dla pieśni zwrotkowej volty - ostatnia kilkutaktowa fraza zostaje powtórzona ze zmianą zakończenia. Charakterystyczne dla Buna-Lied są rytmy marszowe oraz

46 Tłumaczenie autora artykułu. Składam serdeczne podziękowania Adrianie Kretkowskiej oraz Susanne Kozubowicz za pomoc i cenne uwagi językowe. 
skoki - kwartowe, kwintowe, sekstowe, a nawet septymowy. Ten ostatni podkreśla słowo „Schritt” (niem. krok) we frazie „und auf Schritt und Tritt geht das Heimweh mit” („i na każdym kroku towarzyszy tęsknota”). Również interwał seksty zdaje się uwypuklać zwrot „wenn uns das Schicksal genarrt” („kiedy przeznaczenie z nas drwi”), czyniąc z niego pełne żalu zawołanie, intensyfikowane wyższym rejestrem, w porównaniu do pierwszej części zdania „Nur die Arbeit macht uns hart” („Tylko praca czyni nas twardymi”), koncypowanej nieznacznie niżej. Ponadto wyszczególnić można kilkutaktowe progresje tego samego materiału muzycznego, które przypadają na istotne słowa: „Heimweh” („tęsknota za domem”), „Leid” („,ierpienie”), „schweren Zeit” („ciężkie chwile”). Przed wejściem refrenu na znaczeniu zyskują słowa opracowane muzycznie półnutami, stanowiące kontrast w porównaniu do dominujących w całej pieśni ćwierćnut i ósemek; są to: "Arbeit winkt” („praca czeka”) oraz „Lied erklingt” („rozbrzmiewa pieśń"). Zabieg ten mógł być wprowadzony przez kompozytora intencjonalnie, w celu zintensyfikowania znaczenia kluczowych słów oddających sens całej pieśni. Ponadto w Buna-Lied pojawia się bardzo dużo pauz, domykających poszczególne myśli zawarte w tekście - w ten sposób kompozytor zostawił śpiewakom miejsce na oddech. Mimo to muzyczne ukształtowanie Buna-Lied nie należy do najłatwiejszych pod względem wykonawczym - wspomniane skoki, szeroki ambitus ( $a-d^{2}$ lub oktawę niżej przy wykonaniu przez głosy męskie), jak również połączenie niemieckiej prozodii tekstu z rytmami punktowanymi mogły być bardzo trudne do zaśpiewania dla więźniów wycieńczonych katorżniczą pracą, głodem, upałem czy mrozem. Z powodu braku relacji szerzej mówiących o tej pieśni, nie można określić, czy weszła ona do mającego swoje rzeczywiste odzwierciedlenie - repertuaru śpiewanego przez wszystkich więźniów. Wiadomo, iż załoga obozu (Auschwitz III) przyzwalała na oficjalne śpiewanie pieśni, lecz tylko i wyłącznie w języku niemieckim, co przemawia za tym, iż Buna-Lied mogła wejść do obiegowego repertuaru obozowego. Jerzy Strzelecki, były więzień, wspomina o innej pieśni w języku polskim śpiewanej spontanicznie, lecz ukradkiem przez więźniów w Monowitz. W dalszym ciągu wspomnień relacjonujący twierdzi, iż nie pamięta innych pieśni dotyczących komanda Buna ${ }^{47}$. Z powodu braku materiału źródłowego pośród

47 Zob. szerzej: Archiwum PMA-B, Zespół Oświadczenia, t. 116, k. 78-82, relacja Jerzego Strzeleckiego. Autor w oświadczeniu twierdzi, iż więźniowie nieoficjalnie 
relacji złożonych głównie przez więźniów-muzyków, a zachowanych w Archiwum Państwowego Muzeum Auschwitz-Birkenau, dotyczącego Buna-Lied, autor postuluje szczególną ostrożność. Niewykluczone, że jakiś cień informacji o tej pieśni zawarty jest w słabo przebadanych pod tym kątem relacjach więźniów niezwiązanych z muzyką.

Drugim zachowanym dziełem jest Kolysanka skomponowana przez Adama Kopycińskiego w obozie macierzystym w 1941 roku, o czym świadczy obszerna tytułowa dedykacja (zob. Aneks II, poz. 1). Utwór jest wyrazem tęsknoty ojca za dzieckiem spowodowanej rozłąką, jest więc dziełem bardzo osobistym i intymnym. Pod względem muzycznym krótkie Allegretto w metrum dwudzielnym oparte jest na stale powtarzanych figuracjach basowych w lewej ręce. Prawa ręka gra natomiast akordy septymowe w przewrotach, grupujące się w małe, dwutaktowe komórki tematyczne (rozwijane następnie poprzez urozmaicenia rytmiczne i fakturalne). W środkowej części miniatury materiał prawej ręki poddany zostaje synkopacji. W tym miejscu można wydzielić trzy warstwy brzmieniowe: dolną z figuracją basową, środkową z sekundowymi przebiegami melodycznymi na pierwszą miarę taktu oraz górną, obejmującą synkopowane akordy. Pod względem dynamiki kompozycja jest bardzo urozmaicona, co powoduje wzmożenie ekspresji - na przestrzeni 41 taktów, w których zamyka się dzieło, pojawia się aż 16 oznaczeń dynamicznych, od piano possibile po mezzo forte.

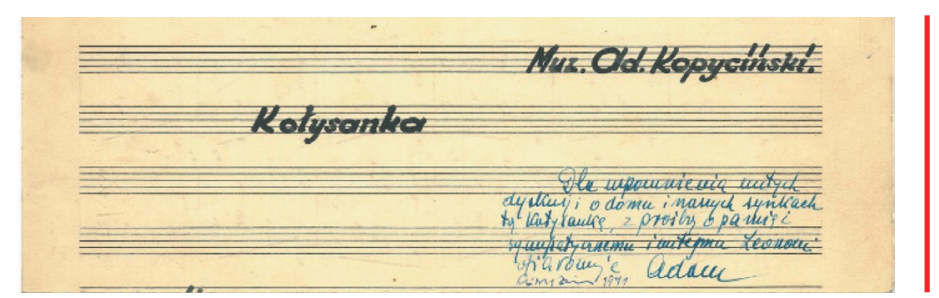

Ilustracja 7. Adam Kopyciński, Kołysanka (rękopis) - tytuł z dedykacją ${ }^{48}$.

śpiewali do melodii pieśni Rozszumiały się wierzby płaczące następujące słowa: „[...] Buna - sławne w obozie komando. Buna postrachem w całym lagrze jest. Lecz ten Bunę przeżyje zwycięsko, kto w lager Auschwitz krwawy przeszedł chrzest [...]". Strzelecki dopowiada, iż nie wie, kto jest autorem słów do tej pieśni. Dalej relacjonuje: „Piosenka śpiewana była spontanicznie, widocznie dobrze odtwarzała panujące wśród nas nastroje. Naturalnie śpiewaliśmy wówczas jeśli było to możliwe, gdy byliśmy sami [...] Nie pamiętam czy podana piosenka miała inne zwrotki. Nie przypominam sobie, byśmy śpiewali inne, podobne w treści piosenki [...]”.

48 Źródło: Zbiory PMA-B, sygn. PMO-II-4-425. 


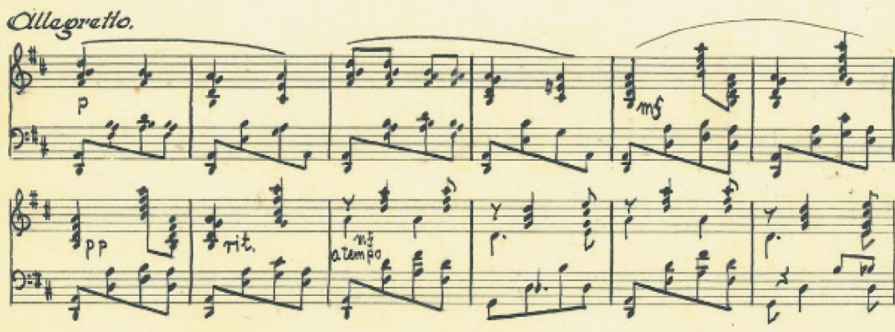

Ilustracja 8. Adam Kopyciński, Kołysanka (rękopis) - dwa pierwsze systemy zapisu nutowego ${ }^{49}$.

Z ostatniego omawianego dzieła skomponowanego przez więźnia Henryka Króla - Arbeitslager Marsch - zachowała się w Dziale Zbiorów PMA-B tylko okładka (zob. Aneks II, poz. 2). Pełen rękopis był w posiadaniu kompozytora, dziś prawdopodobnie znajduje się już w rękach jego krewnych. Państwowe Muzeum Auschwitz-Birkenau dysponuje jednak fotokopią kompozycji. Widząc dzieło po raz pierwszy autor niniejszego artykułu stwierdził, iż owa odbitka z pewnością nie jest rękopisem, z którego grano w czasie, gdy obóz istniał. Świadczy o tym papier nutowy, na którym spisano marsz. Jest to najprawdopodobniej zeszyt nutowy wyprodukowany przez Polskie Wydawnictwo Muzyczne - w lewym dolnym rogu arkusza widnieje matryca (wPm 14). Wydawnictwo to powstało dopiero w 1945 roku. Rękopis, z którym mamy do czynienia, jest zatem powojenną próbą odtworzenia przez kompozytora dzieła wykonywanego w obozie macierzystym. Kopia tego rękopisu obejmuje 26 kart. Są to wyłącznie głosy instrumentalne (brak partytury), przeznaczone dla kwintetu smyczkowego, fletów (2), obojów (2), klarnetów (2), fagotów (2), waltorni (4), trąbek (2), puzonów (3), tuby oraz werbla. Marsz zbudowany jest $\mathrm{z}$ dwóch części. Pierwsza, w B-dur, rozpoczyna się siedmiotaktowym fanfarowym solo trąbek, po którym następuje tutti. W części tej przeważa ruch melodyczny oparty na rozłożonych akordach, w odcinku końcowym partia solowa zostaje powierzona fletom, klarnetom i wiolonczelom. Część środkowa - Trio w As-dur - rozpoczyna się od wtrącenia do f-moll. W zakresie budowy formalnej można przedstawić ją za pomocą schematu: 4-taktowy wstęp + ABA'. Wstęp i środkowa cząstka B utrzymane są w tonacji paraleli, zaś cząstki A i A’ w tonacji głównej (As-dur) tego marsza. Analizując

49 Źródło: Zbiory PMA-B, sygn. PMO-II-4-425. 
warstwę rytmiczną zauważyć można, że w całym dziele na znaczeniu zyskują triolowe ukształtowania ćwierćnutowe i ósemkowe (często legowane) przy permanentnym akcentowaniu mocnej części taktu cechy charakterystycznej dla formy marsza. Lachendro twierdzij ${ }^{50}$, iż kompozycja podobna jest do Marsza Radetzky'ego.

Należy wspomnieć również - mimo niezachowania się powstałego w obozie rękopisu - o Trzech polonezach warszawskich Szymona Laksa. Jest to właściwie opracowanie polonezów nieznanego XVIII-wiecznego autora, których rękopis odnalazł kompozytor w obozie Birkenau niedługo po tym, jak został kapelmistrzem zespołu męskiego Auschwitz II ${ }^{51}$. Niestety, podczas badań w Dziale Zbiorów Państwowego Muzeum Auschwitz-Birkenau - gdzie, jak można przypuszczać, ów pierwotny rękopis powinien się znajdować - autor niniejszego artykułu nie natrafił na żaden jego ślad. Być może znaleziony w Birkenau i cytowany przez Laksa we wspomnieniach zapis polonezów nieznanego autora jeszcze istnieje, lecz wciąż nie został przekazany do muzeum? Może w rękach osób trzecich istnieje dziś także opracowanie owych polonezów, pisane ręką Szymona Laksa w Birkenau? Szczęśliwie kompozytor w 1947 roku odtworzył Trzy polonezy warszawskie - wydało je później Polskie Wydawnictwo Muzyczne ${ }^{52}$.

\title{
Zakończenie
}

\author{
[...] uważam za swój obowiązek spróbować opowiedzieć i jakoś uwiecznić ten \\ skądinąd znamienny rozdział „historii muzyki”, którym chyba się nie zajmie \\ żaden zawodowy historyk tej gałęzi sztuki ${ }^{53}$.
}

Zmierzając do „podwójnej kreski taktowej” powyższego artykułu, nasuwają się autorowi powyższe słowa Szymona Laksa, napisane przez kompozytora pod koniec życia. Oddają one w najlepszy sposób stan piśmiennictwa o muzyce w obozie Auschwitz-Birkenau jeszcze w latach

\footnotetext{
50 J. Lachendro, dz. cyt., s. 49.

51 Sz. Laks, dz. cyt., s. 67.

52 Zob. 3 polonezy warszawskie. Muzyka nieznanego autora $z$ XVIII wieku, oprac. Sz. Laks, Kraków 1950.

53 Sz. Laks, dz. cyt., s. 10.
} 
osiemdziesiątych ubiegłego stulecia, szczególnie w Polsce. Aktualny stan badań dotyczący podjętej tu tematyki pozwala przypuszczać, że nasza wiedza na temat muzyki tworzonej w KL Auschwitz-Birkenau jest coraz bardziej pogłębiona i tym samym w coraz większym stopniu umożliwia podtrzymanie pamięci o aktywności muzycznej więzionych tam kompozytorów i muzyków-wykonawców. Do powszechnego obiegu informacyjnego wyniki badań zostają wprowadzane jednak dość powoli. Stąd w encyklopediach i leksykonach, ale również syntetycznych opracowaniach historii muzyki wydawanych do końca poprzedniego stulecia nie poświęcono temu zagadnieniu jakiejkolwiek uwagi. Hasło Holocaust Music pojawia się tylko w The New Grove Dictionary of Music and Musicians pod redakcją Stanleya Sadiego ${ }^{54}$, natomiast francuska encyklopedia Musiques. Une Encyclopédie pour le XXe siècle pod redakcją Jean-Jacques’a Nattieza poświęca muzyce w obozach hitlerowskich osobny rozdział ${ }^{55}$. Ponadto Oxford University wydało w 2006 roku leksykon Music in the Holocaust. Confronting Life in the Nazi Ghettos and Camps ${ }^{56}$.

$\mathrm{Na}$ swojego badacza wciąż czeka aktywność wokalna więźniów KL Auschwitz-Birkenau. Również rzetelna konfrontacja aktualnych badań kapel oświęcimskich $\mathrm{z}$ wiedzą o muzyce wykonywanej w innych obozach hitlerowskich staje się wyzwaniem dla kolejnych pokoleń uczonych. Trudno jest wyodrębnić dział muzykologii, który miałby się zająć działalnością muzyczną w obozach koncentracyjnych, gdyż zagadnienie czerpie z wielu dziedzin granicznych - socjologii muzyki, psychologii społecznej, psychologii muzyki, estetyki muzyki ${ }^{57}$ i wielu innych dyscyplin naukowych. Świadczy to o złożoności tematu, ale także o jego ogromnej wadze. Autor żywi ogromną nadzieję, iż ów temat doczeka się kompleksowego opracowania przez zespół współpracujących ze sobą ekspertów różnych dziedzin naukowych.

54 A. Knapp, Holocaust, [w:] The New Grove Dictionary od Music and Musicians, red. S. Sadie, t. 13, New York 2001, s. 96-112.

55 J.J. Nattiez, M. Bent, R. Dalmonte, M. Baroni, Musiques. Une Encyclopédie pour le $X X^{e}$ siècle, t. 1, Paris 2003.

56 G. Shirley, Music in the Holocaust. Confronting Life in the Nazi Ghettos and Camps, New York 2006.

57 Więcej o próbie rozpatrywania tej tematyki z punktu widzenia nauk społecznych zob. K. Naliwajek-Mazurek, The Functions of Music within the Nazi System of Genocide in Occupied Poland, [w:] W. Klimczyk, A. Świerzowska, Music and Genocide, seria «Studies in Social Sciences, Philosophy and History of Ideas», t. 9, Frankfurt am Main 2015. 


\section{Aneks I. Instrumenty i akcesoria muzyczne przechowywane w Dziale Zbiorów PMA-B}

\section{Klarnet B}

Sygnatura: PMO-II-4-179

Skrócony opis: Instrument pochodzący z kapeli KL Auschwitz I oraz III (Monowitz). Pod ustnikiem napis: „V. Kohlert's / Söhne / Graslitz”. Na baryłce instrumentu napis: „Made in Czechoslovakia / Amati Toneking”. Na czarze instrumentu wyryta liczba „232”, stanowiąca numer ewidencyjny instrumentu w orkiestrze obozowej (informacja w karcie katalogu) lub numer producenta. Brak oryginalnego futerału. Instrument należał do więźnia Ignacego Stopki (nr więźniarski: 86261), grającego w orkiestrze obozu macierzystego od marca 1943 roku oraz przeniesionego we wrześniu tego roku do obozu w Monowitz (Auschwitz III). Stopka zabrał ze sobą klarnet podczas ewakuacji obozu. Został następnie przewieziony do KL Nordhausen-Dora, wyzwolony w obozie Bergen-Belsen. Wracając do Polski przywiózł ze sobą klarnet. Twierdził, że instrument był własnością jego kolegi Dulina, który zmarł w obozie.

Bibliografia: Archiwum PMA-B, Zespół Oświadczenia, t. 45, k. 113-115, 121, relacja Ignacego Stopki.

\section{Skrzypce}

Sygnatura: PMO-II-4-314

Skrócony opis: Instrument pochodzący z kapeli KL Auschwitz I, wraz ze smyczkiem i futerałem. Wyprodukowany prawdopodobnie w drugiej połowie XIX lub na początku XX wieku. Wewnątrz instrumentu (pod efami) naklejka z dwiema okrągłymi, niewielkimi pieczęciami, na których widnieje napis „Fabrik Marke”, pomiędzy nimi zakurzony, nieczytelny odręczny napis (prawdopodobnie numer produkcji). Kołek przesunięty na prawą stronę. Struny nienaciągnięte. Naciąg strun inkrustowany. Do rączki przymocowana drutem okrągła metalowa blaszka z wytłoczonym numerem „27”. Numer ten jest numerem inwentarzowym instrumentu w orkiestrze obozowej, a jednocześnie w tym przypadku - kolejnym numerem członka orkiestry. Futerał tekturowy, oklejony czarnym introligatorskim płótnem. Uchwyt futerału stanowi rączka $\mathrm{z}$ paska skórzanego. Ponadto w schowku wewnątrz futerału dwie podpórki, jedna mniejsza z napisem „VUILLAUME”, oraz 
smyczek z wyrwanym z żabki włosiem. Instrument nadaje się do zbadania przez specjalistę lutnika w celu opisu szczegółowego i wydania dalszych wskazówek odnośnie konserwacji i przechowywania.

Skrzypce należały do Franciszka Stryja (nr więźniarski: 11091), który został aresztowany przez gestapo w Zabrzu w marcu 1941 roku i przetransportowany do Auschwitz 25 III 1941 roku. Stryj opisuje pobicie Józefa Piaseckiego (basisty) przez Franza Nierychłę - pierwszego dyrygenta orkiestry obozu macierzystego. Skrzypek poszedł wyrazić współczucie dla basisty, który w zamian pomógł mu dostać się do orkiestry. Aby zdać egzamin do zespołu, napisał list do domu z prośbą o przysłanie mu skrzypiec. Jego żona przyjechała do Oświęcimia i na tutejszej poczcie nadała instrument, by skrócić drogę przesyłki. Instrument przyjechał z domu w opłakanym stanie - złamany podstawek, zerwana struna, rozstrojony. Naprawił je Adam Wysocki - gospodarz sali muzycznej. Stryj grał na skrzypcach egzamin u Nierychły - ten kazał mu czytać a vista uwerturę do operetki Dichter und Bauer (Franza von Suppé) oraz marsz Salve imperator (prawdopodobnie Juliusa Fučíka). Poprzednim właścicielem instrumentu był ojciec Stryja. Młody skrzypek grał w kapeli Auschwitz I tylko do lipca 1941 roku, potem zachorował na tyfus plamisty. Miał zostać skierowany na rozprawę przed Sondergerichtem i przesłany do innego więzienia. Rzeczy osobiste Stryja, w tym skrzypce, odebrał jego ojciec. Po wojnie F. Stryj przesłał swój instrument do Działu Zbiorów PMA-B. Bibliografia: Archiwum PMA-B, Zespół Oświadczenia, t. 96, k. 16-21, relacja Franciszka Stryja.

\section{Akordeon}

\section{Sygnatura: PMO-II-4-441}

Skrócony opis: Instrument marki „Sovereign” ze 120 basami, w czarnym futerale. W obozie na instrumencie grał Jan Baraniok (nr więźniarski: 7649). W karcie katalogowej występuje informacja, że instrument został przesłany do obozu przez rodziców więźnia, jednak sam Baraniok opisuje w swej relacji, że w obozie było w tym czasie kilka akordeonów zakupionych przez władze obozu ze składek więźniów. Muzyk został aresztowany 18 XII 1940 roku i tego samego dnia przetransportowany do KL Auschwitz. Podkreśla, że umiał grać na akordeonie i gra dla więźniów funkcyjnych ratowała mu życie. Następnie w swojej relacji daje szczegółowe sprawozdanie na temat powstawania kapeli w obozie macierzystym. Brak informacji o dalszych losach instrumentu. 
Bibliografia: Archiwum PMA-B, Zespół Oświadczenia, t. 33, k. 59-60, relacja Jana Baranioka.

\section{Tuba basowa - „basy Beiny”}

Sygnatura: PMO-II-4-495

Skrócony opis: Na instrumencie wyryty napis producenta „Otto Singer Desau”. Instrument był własnością więźnia Bolesława Majcherczyka (nr więźniarski: 24913), który grał na trąbie w kapeli obozu macierzystego Auschwitz I oraz w obozie Bergen-Belsen. Kolega Sapiński napisał $w$ jego imieniu list do rodziny $z$ prośbą o przesłanie instrumentu $\mathrm{z}$ domu. Instrument otrzymał w obozie numer inwentarzowy „158” (wyryty na małej blaszce). Majcherczykowi udało się zabrać ze sobą instrument podczas ewakuacji i transportu do KL BergenBelsen. Następnie przewieziono muzyka do KL Dora, tam grał nadal w orkiestrze na tym instrumencie. W 1989 roku Bolesław Majcherczyk przekazał akordeon Działowi Zbiorów PMA-B.

Bibliografia: Archiwum PMA-B, Zespół Oświadczenia, t. 73, k. 86-88, relacja Bolesława Majcherczyka.

\section{Pulpit nutowy}

Sygnatura: PMO-II-4-429

Skrócony opis: W karcie katalogu nazwa: „stojak na nuty”. Fragment zniszczonego pulpitu nutowego. Brak podstawy, tylko fragment nóżki. Brak dostępnych informacji, do której kapeli w obozach oświęcimskich należał.

\section{Aneks II. Utwory skomponowane w KL Auschwitz-Birkenau - rękopisy zachowane w Dziale Zbiorów PMA-B}

1. Tytuk: Kolysanka

Autor: Adam Kopyciński

Sygnatura: PMO-II-4-425

Skrócony opis: Rękopis sporządzony na arkuszu nutowym zajmujący 3 karty (3 systemy nutowe wycięte $\mathrm{z}$ jednego arkusza pięciolinii Beethoven Papier Nr. 33 [16 Linen]). Na pierwszej stronie odręczna dedykacja: „Muz. Ad. Kopyciński. / Kołysanka / Dla wspomnienia miłych 
dyskusji o domu i naszych synkach tą kołysankę, z prośbą o pamięć sympatycznemu i miłemu Leonowi ofiarowuje Adam / Oświęcim 1941”.

2. Tytul: Arbeitslager / Marsch / Heinrich Krol

Autor: Henryk Król

Sygnatura: PMO-II-4-198

Skrócony opis: Biała okładka z partytury marsza pt. Arbeitslagermarsch. Tytuł zapisany odręcznie czarnym tuszem, pod tytułem narysowana lira i liście róży. $U$ dołu nazwisko kompozytora w pisowni niemieckiej. Dzieło skomponowane w 1941 r. przez Henryka Króla (nr więźniarski: 1183). Kompletne dzieło (rękopiśmienne głosy, brak partytury) jest obecnie w posiadaniu rodziny autora.

\section{Tytuł: Buna-Lied}

Autor: muzyka: Anton Geppert, tekst: Fritz Löhner

Sygnatura: PMO-II-4-456

Skrócony opis: Rękopis pieśni śpiewanej w KL Monowitz (Auschwitz III). Pod tytułem napis: „Text von Dr. Fritz Löhner (Beda), gestorben in Monowitz am 4.12.1942. / Musik von Anton Geppert, Wien”. Rękopis składa się z ośmiu pięciolinii z zapisem nutowym i tekstem pod nutami (1 karta). Na rewersie rękopisu, u dołu z prawej strony, odręczny napis ołówkiem: „Bausch podziękować dla Zw w Austrii Danimann”, będący powojenną adnotacją pracownika PMA-B, prawdopodobnie J.A. Brandhubera.

\section{Aneks III. Pozostałe zachowane dzieła (druki muzyczne) prze- chowywane w Dziale Zbiorów PMA-B}

\section{a. Kompozycje zidentyfikowane}

Poniżej przedstawiono źródła w ujęciu chronologicznym według dat urodzenia twórców. Ponadto w celu zwiększenia przejrzystości tekstu wprowadzono kilka skrótów: w nawiasach kwadratowych [ ] podano sygnaturę miejsca w Dziale Zbiorów Państwowego Muzeum Auschwitz-Birkenau; (T) - teczka, na której widnieje tytuł dzieła (nie zawsze zgodny z jej zawartością); (ZW) - zamówienie wydawnicze, 
wklejone w zielone teczki, na którym widnieje tytuł dzieła, czasem wyszczególnione głosy orkiestrowe; (KRG) - kopia rękopiśmienna głosów orkiestrowych, wykonywana przez więźniów kopistów nut z druków muzycznych; (R) - rękopis; (D) - druk muzyczny, oznaczenie pojawia się tylko w przypadkach wątpliwych; jeśli obok dzieła nie pojawia się żaden z tych symboli - również oznacza to druk muzyczny.

\begin{tabular}{|l|l|}
\hline $\begin{array}{l}\text { Antonio Vivaldi } \\
\text { (1678-1741) }\end{array}$ & $\begin{array}{l}\text { Koncert na dwoje skrzypiec a-moll (Concerto la mineur) } \\
\text { pour 2 Violons, Orchestre à cordes et orgue ou 2 Violons et } \\
\text { Piano, RV 522 [PMO-II-4-185] }\end{array}$ \\
\hline $\begin{array}{l}\text { Georg Friedrich } \\
\text { Händel } \\
\text { (1685-1759) }\end{array}$ & $\begin{array}{l}\text { Stücke Alter Meister / für / Violine und Klavier / Fortsetzung / } \\
\text { der von Willy Burmester begonnen Sammlung / Neu bear- } \\
\text { beitet von / Gustav Hollander / No. 41 } \\
\text { Händel Sarabande, wyd. Ad. Köster, Berlin } \\
\text { [PMO-II-4-186/1,2] } \\
\text { Largo / Aria aus der Oper: Xerxes [PMO-II-4-630/14 (T)] }\end{array}$ \\
\hline $\begin{array}{l}\text { Johann } \\
\text { (1685-1750) }\end{array}$ & $\begin{array}{l}\text { Stücke Alter Meister / für / Violine und Klavier / Fortsetzung / } \\
\text { der von Willy Burmester begonnen Sammlung / Neu } \\
\text { bearbeitet von / Gustav Hollander / No. 38 Bach Bourrée, } \\
\text { wyd. Ad. Köster, Berlin [PMO-II-4-186/1,2] }\end{array}$ \\
\hline $\begin{array}{l}\text { Joseph Haydn } \\
\text { (1732-1809) }\end{array}$ & $\begin{array}{l}\text { Symphonien für Pianoforte zu 4 Händen, Band I, No. 125I, } \\
\text { wyd. B\&H, Leipzig [sygn. PMO-II-4-460] } \\
\text { Stücke Alter Meister / für / Violine und Klavier / Fortsetzung / } \\
\text { der von Willy Burmester begonnen Sammlung / Neu bear- } \\
\text { beitet von / Gustav Hollander / No. 39 } \\
\text { No. 40 Haydn Capriccio, wyd. Ad. Köster, Berlin } \\
\text { [PMO-II-4-186/1,2] } \\
\text { Symphonie mit dem Paukens [PMO-II-4-583/68 (ZW)] }\end{array}$ \\
\hline $\begin{array}{l}\text { Friedrich Wilhelm } \\
\text { Rust } \\
\text { (1739-1796) }\end{array}$ & $\begin{array}{l}\text { Chinesischer Teehändler / Scène caractéristique, ar. Hartwig } \\
\text { von Platen, wyd. Richard Birnbach, Berlin [PMO-II-4-583/30 } \\
\text { (pod sygn. PMO-II-4-583/30: T)] } \\
\text { Slawische Rhapsodie, ar. Hartwig von Platen, wyd. Richard } \\
\text { Birnbach, Berlin [PMO-II-4-583/6] } \\
\text { Slawische Rhapsodie / Klavier-Cadenz, kadencja forte- } \\
\text { pianowa do powyższej Rapsodii, napisana przez jednego } \\
\text { z więźniów (podpis nieczytelny) [PMO-II-4-596 (R-2 k.)] } \\
\text { Schwabenmädel / Walzer, ar. Hartwig von Platen, } \\
\text { wyd. Richard Birnbach, Berlin [PMO-II-4-583/43] } \\
\text { Kleine Ouverture / Lachendes leben [PMO-II-4-583/64 (ZW)] } \\
\text { Fantasie für jazzorchester Colibri [PMO-II-4-382 (ZW)] }\end{array}$ \\
\hline
\end{tabular}




\begin{tabular}{|c|c|}
\hline $\begin{array}{l}\text { Wolfgang Amadeus } \\
\text { Mozart } \\
(1756-1791)\end{array}$ & $\begin{array}{l}\text { Sinfonie D-dur (mit Menuett) KV 385, wyd. Otto } \\
\text { Wrede Regina Verlag, Berlin [PMO-II-4-367] } \\
\text { Die Zauberflöte - Ouvertüre, wyd. B\&H, Leipzig } \\
\text { [PMO-II-4-195] } \\
\text { Die Entführung aus dem Serail - Ouvertüre KV 384, } \\
\text { wyd. B\&H, Leipzig [PMO-II-4-349 (pod sygn. } \\
\text { PMO-II-4-583/59: ZW)] } \\
\text { Stücke Alter Meister / für / Violine und Klavier / } \\
\text { Fortsetzung / der von Willy Burmester begonnen } \\
\text { Sammlung / Neu bearbeitet von / Gustav Hollander } \\
\text { / No. 39 Mozart Gavotte, wyd. Ad. Köster, Berlin } \\
\text { [PMO-II-4-186/1,2] }\end{array}$ \\
\hline $\begin{array}{l}\text { Luigi Cherubini } \\
(1760-1842)\end{array}$ & Die Abenceragen - Oüverture [PMO-II-4-378: ZW] \\
\hline $\begin{array}{l}\text { Ludwig van Beethoven } \\
\text { (1770-1827) }\end{array}$ & $\begin{array}{l}\text { V Symfonia c-moll op. 67, wyd. B\&H, Leipzig } \\
\text { [PMO-II-4-180 (pod sygn. PMO-II-4-391: T)] } \\
\text { Stücke Alter Meister / für / Violine und Klavier / } \\
\text { Fortsetzung / der von Willy Burmester begon- } \\
\text { nen Sammlung / Neu bearbeitet von / Gustav } \\
\text { Hollander / No. } 37 \text { Beethoven Contretanz, } \\
\text { wyd. Ad. Köster, Berlin [PMO-II-4-186/1,2] } \\
\text { Klavier-Konzert... Nr } 5 \text { [PMO-II-4-389: ZW] }\end{array}$ \\
\hline $\begin{array}{l}\text { Johann Baptist Cramer } \\
(1771-1858)\end{array}$ & $\begin{array}{l}\text { Stücke Alter Meister / für / Violine und Klavier / } \\
\text { Fortsetzung / der von Willy Burmester begon- } \\
\text { nen Sammlung / Neu bearbeitet von / Gustav } \\
\text { Hollander / No. } 42 \text { Cramer Walzer, wyd. Ad. Köster, } \\
\text { Berlin [PMO-II-4-186/1,2] }\end{array}$ \\
\hline $\begin{array}{l}\text { Carl Maria von Weber } \\
(1786-1826)\end{array}$ & $\begin{array}{l}\text { Jubel - Ouvertüre, wyd. Verlag von Anton } \\
\text { J. Benjamin, Hamburg-Leipzig-Mailand } \\
\text { [PMO-II-4-583/4] } \\
\text { Beherrscher der Geister-Ouvertüre } \\
\text { [PMO-II-4-610: ZW] }\end{array}$ \\
\hline $\begin{array}{l}\text { Franz Schubert } \\
(1797-1828)\end{array}$ & $\begin{array}{l}\text { Duos für Pianoforte und Violine op. } 137 \mathrm{nr} \text { 1-3, } \\
\text { wyd. Edition Peters, Leipzig [PMO-II-4-184] }\end{array}$ \\
\hline $\begin{array}{l}\text { Hector Berlioz } \\
(1803-1869)\end{array}$ & $\begin{array}{l}\text { Le Carnaval Romain - Ouverture caractéris- } \\
\text { tique, ar. Henry Weber, wyd. Edition Cranz (brak } \\
\text { miejsca wydania) [PMO-II-4-583/57 } \\
\text { (pod sygn. PMO-II-4-630/21: T)] }\end{array}$ \\
\hline $\begin{array}{l}\text { Fryderyk Chopin } \\
\text { (1810-1849) }\end{array}$ & $\begin{array}{l}\text { Polonez / A dur (wersja koncertowa) } \\
\text { [PMO-II-4-601: T] }\end{array}$ \\
\hline $\begin{array}{l}\text { Friedrich von Flotow } \\
(1812-1883)\end{array}$ & $\begin{array}{l}\text { Ouvertüre zur Oper: / Martha / No. 1, } \\
\text { ar. L. Weninger [PMO-II-4-583/81] }\end{array}$ \\
\hline
\end{tabular}




\begin{tabular}{|c|c|}
\hline $\begin{array}{l}\text { Richard Wagner } \\
(1813-1883)\end{array}$ & $\begin{array}{l}\text { Erinnerung an Richard Wagners Rienzi, ar. Otto Hohmann, } \\
\text { wyd. Anton J. Benjamin Musikverlag, Leipzig-Milano } \\
\text { [PMO-II-4-583/1] } \\
\text { Erinnerung an Richard Wagners Lohengrin, ar. Otto } \\
\text { Hohmann, wyd. J. Anton, J. Benjamin, Hamburg } \\
\text { [PMO-II-4-618] } \\
\text { Wagners Heldenbuch / Fantasie, ar. Ernst Urbach, wyd. Otto } \\
\text { Wrede Regina-Verlag, Berlin [PMO-II-4-602] } \\
\text { Das Liebesmahl der Apostel [PMO-II-4-392: T] } \\
\text { Kleine Fantasie über R. Wagners / Lohengrin, ar. Fr. Eberle } \\
\text { [PMO-II-4-583/72: ZW] }\end{array}$ \\
\hline $\begin{array}{l}\text { Giuseppe Verdi } \\
(1813-1901)\end{array}$ & $\begin{array}{l}\text { Rigoletto - Fantasie Sélection, opr. Leopold Weninger, } \\
\text { wyd. D. Räder, Leipzig [PMO-II-4-583/19, PMO-II-4-630/20, } \\
\text { PMO-II-4-597: KRG: Sax. B] } \\
\text { Un ballo in maschera / Potpourri, ar. Rich. Atzler, } \\
\text { wyd. August Cranz, Leipzig [PMO-II-4-605] }\end{array}$ \\
\hline $\begin{array}{l}\text { Jacques } \\
\text { Offenbach } \\
(1819-1880)\end{array}$ & $\begin{array}{l}\text { La belle Helene / Fantasie, ar. Rich. Atzler, wyd. Edition } \\
\text { Cranz, Leipzig [PMO-II-4-583/73] }\end{array}$ \\
\hline $\begin{array}{l}\text { Franz von Suppé } \\
(1819-1895)\end{array}$ & $\begin{array}{l}\text { Fantasie aus der Operette: / Fatinitza, ar. Rich. Atzler, } \\
\text { wyd. Edition Cranz, Leipzig [PMO-II-4-583/73 (pod sygn. } \\
\text { PMO-II-4-630/24: T; PMO-II-4-394 - ZW) } \\
\text { Die schöne Galathe / Potpourri aus der komischen Operette } \\
\text { (brak informacji o autorze opracowania), wyd. Aug. Cranz } \\
\text { GmbH., Leipzig [PMO-II-4-583/58] } \\
\text { Zehn Mädchen und kein Mann / Ouverture zur komischen } \\
\text { Oper, ar. Rich. Atzler, wyd. Edition Cranz, Leipzig } \\
\text { [PMO-II-4-583/60] } \\
\text { Ein Wiener Souper / Fantasie / über /Suppé'sche Melodien, } \\
\text { opr. Victor Hruby, wyd. Edition-Cranz, Leipzig } \\
\text { [PMO-II-4-191/1-3] } \\
\text { Das ist mein Oesterreich, wyd. Verlag Anton J. Benjamin, } \\
\text { Leipzig-Milano [PMO-II-4-464: D oraz KRG] }\end{array}$ \\
\hline $\begin{array}{l}\text { Édouard Lalo } \\
(1823-1892)\end{array}$ & $\begin{array}{l}\text { Ouvertüre zur Oper Le Roi d'Ys, ar. E. Haensch } \\
\text { [PMO-II-4-461] }\end{array}$ \\
\hline $\begin{array}{l}\text { Johann Strauss } \\
(1825-1899)\end{array}$ & $\begin{array}{l}\text { Potpourri aus: / Das Spitzentuch der Königin, ar. Henry } \\
\text { Weber, wyd. Aug. Cranz, GmbH., Leipzig [PMO-II-4-583/71] } \\
\text { Potpourri aus der Operette / Ein Nacht in Venedig, ar. Henry } \\
\text { Weber, wyd. Aug. Cranz, GmbH., Leipzig [PMO-II-4-583/74] } \\
\text { Potpourri aus der Operette: / } 1001 \text { Nacht, ar. Henry Weber, } \\
\text { wyd. Aug. Cranz, GmbH., Leipzig [PMO-II-4-630/1] } \\
\text { Der Karneval in Rom - Ouvertüre [PMO-II-4-583/66: T] }\end{array}$ \\
\hline $\begin{array}{l}\text { August Lanner } \\
(1835-1855)\end{array}$ & $\begin{array}{l}\text { Die erste Gedanken, ar. Erich Frost, wyd. Edition Cranz, } \\
\text { Leipzig [PMO-II-4-583/69] }\end{array}$ \\
\hline
\end{tabular}




\begin{tabular}{|c|c|}
\hline $\begin{array}{l}\text { Piotr Iljicz } \\
\text { Czajkowski } \\
(1840-1893)\end{array}$ & $\begin{array}{l}\text { Peter Tschaikowsky - Konzert-Suite / (in } 4 \text { Sätzen), ar. Josef } \\
\text { Németi, wyd. Kistner \& Siegel, Leipzig [PMO-II-4-583/11 } \\
\text { (pod sygn. PMO-II-4-583/67: T)] } \\
\text { Eugen Onegin / Grosse Fantasie [PMO-II-4-583/62: T] }\end{array}$ \\
\hline $\begin{array}{l}\text { Alphons Czibulka } \\
(1842-1894)\end{array}$ & $\begin{array}{l}\text { Gavotte - Stephanie op. 312, ar. L. Artok, wyd. B. Schotts } \\
\text { Söhne, Mainz [PMO-II-4-583/76, PMO-II-4-630/21] }\end{array}$ \\
\hline $\begin{array}{l}\text { Jules Massenet } \\
(1842-1912)\end{array}$ & $\begin{array}{l}\text { Scénes Dramatiques - Prélude, ar. L. Artok, wyd. B. Schotts } \\
\text { Söhne, Mainz [PMO-II-4-583/17] }\end{array}$ \\
\hline $\begin{array}{l}\text { Edward Grieg } \\
(1843-1907)\end{array}$ & $\begin{array}{l}\text { Am der Frühling op. } 43 \text { nr 6, ar. Gottfr. Huppertz, } \\
\text { wyd. C.F. Peters, Leipzig [PMO-II-4-583/40] } \\
\text { Peer Gynt Suite I op. 46, ar. L. Weninger, wyd. C.F. Peters, } \\
\text { Leipzig [PMO-II-4-189/1-44 (pod sygn. PMO-II-4-583/67: ZW)]. } \\
\text { Peer Gynt Suite II op. 55, ar. L. Weninger, wyd. C.F. Peters, } \\
\text { Leipzig [PMO-II-4-630/18, PMO-II-4-630/22] } \\
\text { Erotik / Poème érotique op. } 43 \text { nr 5, ar. Gottfr. Huppertz, } \\
\text { wyd. C.F. Peters, Leipzig [PMO-II-4-583/22] }\end{array}$ \\
\hline $\begin{array}{l}\text { Carl Michael } \\
\text { Ziehrer } \\
(1843-1922)\end{array}$ & $\begin{array}{l}\text { Ouvertüre / zur der Operette Die Landstreicher, ar. Josef } \\
\text { Stumpf, wyd. Ludwig Doblinger, Wien-Berlin-Leipzig } \\
\text { [PMO-II-4-630/3] } \\
\text { Der Zauber der Montur Marsch [PMO-II-4-386: ZW] } \\
\text { Unanfechtbar Marsch [PMO-II-4-386: ZW] }\end{array}$ \\
\hline $\begin{array}{l}\text { Nikołaj } \\
\text { Andriejewicz } \\
\text { Rimski-Korsakow } \\
\text { (1844-1908) }\end{array}$ & $\begin{array}{l}\text { Capriccio Espagnol op. 34, transkr. Th. Hartmann, } \\
\text { wyd. M.P. Belaieff, Leipzig [PMO-II-4-183] }\end{array}$ \\
\hline $\begin{array}{l}\text { Richard } \\
\text { Eilenberg } \\
(1848-1927)\end{array}$ & $\begin{array}{l}\text { Schwarzwald Ein Idyll op. 52/ Le moulin de la forêt noire } \\
\text { [PMO-II-4-188/1-14] }\end{array}$ \\
\hline $\begin{array}{l}\text { Karel Komzák } \\
(1850-1905)\end{array}$ & $\begin{array}{l}\text { Neue Wiener Volksmusik / Potpourri, wyd. Julius Chmel } \\
\text { [PMO-II-4-583/20] } \\
\text { Echtes Wienerblut [PMO-II-4-385: ZW] }\end{array}$ \\
\hline $\begin{array}{l}\text { Karl Wilhelm } \\
\text { Drescher } \\
(1850-1925)\end{array}$ & Linzer Nuam / Marsch [PMO-II-4-630/15: ZW] \\
\hline $\begin{array}{l}\text { Robert Vollstedt } \\
(1854-1919)\end{array}$ & $\begin{array}{l}\text { Japanische Wachtparade op. 92, wyd. Aug. Cranz, Hamburg } \\
\text { [PMO-II-4-583/38 (pod sygn. PMO-II-4-593: KRG)] }\end{array}$ \\
\hline $\begin{array}{l}\text { Engelbert } \\
\text { Humperdinck } \\
(1854-1921)\end{array}$ & Vorspiel / Hansel und Grettel [PMO-II-4-583/53: ZW] \\
\hline $\begin{array}{l}\text { Oskar Fetrás } \\
(1854-1931)\end{array}$ & $\begin{array}{l}\text { Tirol in Lied und Tanz / Divertissement op. 139, wyd. Anton } \\
\text { J. Benjamin, Leipzig [PMO-II-4-583/70] } \\
\text { Schleswig-Holstein / Marsch [PMO-II-4-601: ZW] }\end{array}$ \\
\hline
\end{tabular}




\begin{tabular}{|l|l|}
\hline $\begin{array}{l}\text { Heinrich Berté } \\
\text { (1858-1924) }\end{array}$ & $\begin{array}{l}\text { Großes Potpourri / nach Motiven des Singspieles: Das } \\
\text { Dreimäderlhaus, instr. Martin Uhl, wyd. Ludwig Doblinger, } \\
\text { Wien-München [PMO-II-4-609] }\end{array}$ \\
\hline $\begin{array}{l}\text { Giacomo Puccini } \\
\text { (1858-1924) }\end{array}$ & $\begin{array}{l}\text { Große Fantasie aus der Oper: / La Bohéme / No. 310 } \\
\text { [PMO-II-4-196] }\end{array}$ \\
\hline $\begin{array}{l}\text { Emil von } \\
\text { Reznicek } \\
\text { (1860-1945) }\end{array}$ & $\begin{array}{l}\text { Ouvertüre zur Oper Donna Diana, ar. B. Leopold, } \\
\text { wyd. Universal Edition, Wien-Leipzig [PMO-II-4-583/14] }\end{array}$ \\
\hline $\begin{array}{l}\text { Erik Meyer- } \\
\text {-Helmund } \\
\text { (1861-1932) }\end{array}$ & $\begin{array}{l}\text { Sérénade-Roccoco, wyd. Bosworth u. Co., London-Leipzig- } \\
\text { Wien-Bruxelles [PMO-II-4-583/54] }\end{array}$ \\
\hline $\begin{array}{l}\text { Franz von Blon } \\
\text { (1861-1945) }\end{array}$ & $\begin{array}{l}\text { Frauen-Liebe und Leben / Walzer, ar. Fr. Schimak, wyd. Otto } \\
\text { Wernthal, Berlin [PMO-II-4-630/19] }\end{array}$ \\
\hline $\begin{array}{l}\text { Richard Strauss } \\
\text { (1864-1949) }\end{array}$ & $\begin{array}{l}\text { Morgen op. 27 nr 4, ar. Arnold Wilke, wyd. Universal Edition, } \\
\text { Wien-Leipzig [PMO-II-4-585] }\end{array}$ \\
\hline $\begin{array}{l}\text { Otto Kockert } \\
\text { (1865-1941) }\end{array}$ & $\begin{array}{l}\text { Der Kleine Pfiffikus op. 98, ar. Carl Zimmer, wyd. Richard } \\
\text { Birnbach, Berlin [PMO-II-4-586] } \\
\text { Intermezzo / Einzug der Frühlingsblumen } \\
\text { [PMO-II-4-583/56: T] }\end{array}$ \\
\hline $\begin{array}{l}\text { Paul Lincke } \\
\text { (1866-1946) }\end{array}$ & $\begin{array}{l}\text { Lasst den Kopf nicht hängen! / Grosses Potpourri, } \\
\text { wyd. Apollo Verlag, Berlin [PMO-II-4-630/5] } \\
\text { Potpourri aus der Operette: / Frau Luna (być może autorem } \\
\text { opracowania jest sam kompozytor), wyd. Apollo-Verlag, } \\
\text { Berlin [PMO-II-4-583/75] } \\
\text { Die Meistersinger von Berlin / Grosses gesangs-Potpourri, } \\
\text { wyd. Apollo-Verlag, Berlin [PMO-II-4-583/52] } \\
\text { Siamesiche Wachtparade Charakterstück, wyd. Apollo- } \\
\text {-Verlag, Berlin [PMO-II-4-187: D oraz KRG] } \\
\text { Berliner Luft / Marsch [PMO-II-4-630/4: T] } \\
\text { Ouvertüre / zur der Operette: / Im Reiche des Indra } \\
\text { [PMO-II-4-583/76: T] } \\
\text { Folies-Bergere [PMO-II-4-387: ZW] }\end{array}$ \\
\hline
\end{tabular}




\begin{tabular}{|c|c|}
\hline $\begin{array}{l}\text { Franz Lehár } \\
\text { (1870-1948) }\end{array}$ & $\begin{array}{l}\text { Immer nur lächeln / Lied aus der romantischen Operette } \\
\text { Das Land des Lächelns, wyd. Glocken-Verlag, Wien } \\
\text { [PMO-II-4-584] } \\
\text { Großes Potpourri / aus / Zigeunerliebe / Operette in } \\
3 \text { Akten, ar. Hans Schott, wyd. Glocken-Verlag, Wien } \\
\text { [PMO-II-4-622] } \\
\text { Schön ist die Welt / Lied aus der Operette, wyd. Glocken- } \\
\text {-Verlag, Wien [PMO-II-4-630/4] } \\
\text { Liebste glaub' an mich! / Lied aus der Operette Schön ist die } \\
\text { Welt, ar. Viktor Hruby, wyd. W. Karczag, Leipzig } \\
\text { [PMO-II-4-630/14] } \\
\text { Grosses Potpourri aus der Operette Schön ist die Welt, } \\
\text { ar. Viktor Hruby, wyd. W. Karczag, Leipzig [PMO-II-4-583/56] } \\
\text { Mädel klein, Mädel fein! / Lied aus der Operette Der Graf } \\
\text { von Luxemburg, wyd. Glocken-Verlag, Wien [PMO-II-4-589] } \\
\text { Melodienfolge / aus der Operette Der Graf von Lusemburg, } \\
\text { wyd. Glocken-Verlag, Wien [PMO-II-4-616] } \\
\text { Großes Potpourri / nach Motiven der Operette Der } \\
\text { Rastelbinder, ar. Gust. Mahr, wyd. Verlag von Josef } \\
\text { Weinberger, Leipzig-Wien [PMO-II-4-630/7] } \\
\text { Grosses Potpourri aus dem Sinspiel: Friederike, ar. Max } \\
\text { Rohlee, wyd. Crescendo Theaterverlag, Berlin } \\
\text { [PMO-II-4-583/49] } \\
\text { Du bist meine Sonne / Lied aus der musikalischen Komödie } \\
\text { Giuditta, ar. Viktor Hruby, wyd. W. Karczag, Leipzig } \\
\text { [PMO-II-4-620] } \\
\text { Ouvertüre / zur der Operette Wiener Frauen, wyd. Glocken- } \\
\text {-Verlag, Wien [PMO-II-4-181/1-12] } \\
\text { Jede Nacht träume ich ... / Lied und Langsamer Walzer, } \\
\text { wyd. Glocken-Verlag, Wien [PMO-II-4-607] } \\
\text { Ungarischer Marsch [PMO-II-4-583/52: ZW] }\end{array}$ \\
\hline $\begin{array}{l}\text { Ernst Urbach } \\
(1872-1927)\end{array}$ & $\begin{array}{l}\text { Apollo - Marsch, ar. Andreas Schorer, wyd. Otto Wrede - } \\
\text { Regina Verlag, Berlin [PMO-II-4-463] }\end{array}$ \\
\hline $\begin{array}{l}\text { Paul Graener } \\
(1872-1944)\end{array}$ & $\begin{array}{l}\text { Sérénade pittoresque, wyd. Richard Birnbach, Berlin } \\
\text { [PMO-II-4-583/33] }\end{array}$ \\
\hline
\end{tabular}




\begin{tabular}{|c|c|}
\hline $\begin{array}{l}\text { S. Coleridge- } \\
\text {-Taylor } \\
(1875-1912)\end{array}$ & $\begin{array}{l}\text { Afrikanische Suite I/ Negro Suite op. 105, ar. L. Artok, } \\
\text { wyd. B. Schotts Söhne, Mainz-Leipzig [PMO-II-4-583/8] } \\
\text { Afrikanische Suite II / Negro Suite op. 105, ar. L. Artok, } \\
\text { wyd. B. Schotts Söhne, Mainz-Leipzig [PMO-II-4-583/9] } \\
\text { Zigeuner Suite / Gipsy Suite op. 104, ar. L. Artok, } \\
\text { wyd. B. Schotts Söhne, Mainz-Leipzig [PMO-II-4-583/12] }\end{array}$ \\
\hline $\begin{array}{l}\text { Rudolf } \\
\text { Kronegger } \\
(1875-1929)\end{array}$ & $\begin{array}{l}\text { Beim Heurigen / Potpourri, ar. F. Muuss, J.K. Richter, } \\
\text { wyd. Bosworth and Co., Leipzig [PMO-II-4-583/15] }\end{array}$ \\
\hline $\begin{array}{l}\text { Fedele Rivelli } \\
(1875-1930)\end{array}$ & $\begin{array}{l}\text { Serenata napolitana / Neapolitanisches Ständchen, } \\
\text { ar. Ernst Urbach, wyd. Otto Wrede, Berlin [PMO-II-4-621] }\end{array}$ \\
\hline $\begin{array}{l}\text { Giuseppe Becce } \\
(1877-1973)\end{array}$ & $\begin{array}{l}\text { Serenata della Laguna op. 32, wyd. Robert Lineau, Berlin } \\
\text { [PMO-II-4-630/23] }\end{array}$ \\
\hline $\begin{array}{l}\text { Hans Ailbout } \\
(1879-1957)\end{array}$ & $\begin{array}{l}\text { Humoreske in C-dur, wyd. Rud. Erdmann u. Co., Leipzig } \\
\text { [PMO-II-4-583/23] } \\
\text { Magdalena / Reminiscenz, wyd. Musikverlag Matth. Hohner } \\
\text { A.G., Berlin [PMO-II-4-583/32] } \\
\text { Rhapsodie Catalan, wyd. Kawi-Verlag, Berlin \& W. Ehrler and } \\
\text { Co., Leipzig [PMO-II-4-583/16] }\end{array}$ \\
\hline $\begin{array}{l}\text { Jacob Gade } \\
(1879-1963)\end{array}$ & $\begin{array}{l}\text { Jalousie / Tango Tzigane, ar. Georges Martine, wyd. Edition } \\
\text { Charles Brüll, Paris [PMO-II-4-389] }\end{array}$ \\
\hline $\begin{array}{l}\text { Wilhelm August } \\
\text { Lautenschläger } \\
\text { [José Armándola] } \\
\text { (1880-1949) }\end{array}$ & $\begin{array}{l}\text { Im Rosenhag / Pizzicato-Ständchen, ar. J. Armándola, } \\
\text { wyd. Richard Birnbach, Berlin [PMO-II-4-630/17] } \\
\text { Gaukler im Dorf / Charakterstück, ar. J. Armándola, wyd. } \\
\text { Richard Birnbach, Berlin [PMO-II-4-583/27, PMO-II-4-630/8] }\end{array}$ \\
\hline $\begin{array}{l}\text { Georg } \\
\text { Freundorfer } \\
(1881-1940)\end{array}$ & $\begin{array}{l}\text { Lustiges Tirol Polka, ar. Johann Voehrs, } \\
\text { wyd. Rud. Erdman \& Co., Leipzig [PMO-II-4-420: D oraz RKG] }\end{array}$ \\
\hline $\begin{array}{l}\text { Wilhelm } \\
\text { Lindemann } \\
(1882-1941)\end{array}$ & Wenn die Soldaten, Marsch [PMO-II-4-388: ZW] \\
\hline $\begin{array}{l}\text { Karl Julius } \\
\text { Sommer } \\
(1883-1962)\end{array}$ & $\begin{array}{l}\text { Suite in } 5 \text { Sätzen / Im sonningen Süden } \\
\text { [PMO-II-4-583/63: ZW] }\end{array}$ \\
\hline $\begin{array}{l}\text { Erich Otto [Erich } \\
\text { Otto Deutsch?, } \\
\text { muzykolog } \\
(1883-1967)]\end{array}$ & $\begin{array}{l}\text { Koketterie / Kleine Serenade / Violinsolo mit } \\
\text { Orchesterbegleitung, ar. Walter Meissner [PMO-II-4-583/39] }\end{array}$ \\
\hline
\end{tabular}




\begin{tabular}{|c|c|}
\hline $\begin{array}{l}\text { Hans Gansser } \\
(1884-1959)\end{array}$ & $\begin{array}{l}\text { Kamerad, die Schicksalsstunde schlägt (Kolego, wybija } \\
\text { godzina przeznaczenia), tekst: Kurt Eggers. Nuty piosenki } \\
\text { marszowej Waffen SS składające się z } 1 \text { karty z zapisem } \\
\text { nutowym na } 6 \text { rzędach pięciolinii i } 4 \text { zwrotkami piosenki } \\
\text { u dołu. [PMO-II-4-462] }\end{array}$ \\
\hline $\begin{array}{l}\text { Heinrich } \\
\text { Steinbeck } \\
(1884-1967)\end{array}$ & $\begin{array}{l}\text { In alter Frische Marsch [PMO-II-4-395: ZW] } \\
\text { Regimentsgruss Marsch [PMO-II-4-395: ZW] }\end{array}$ \\
\hline $\begin{array}{l}\text { Eduard Künnecke } \\
\text { (1885-1953) }\end{array}$ & $\begin{array}{l}\text { Blaue Jungs fahren zur See, ar. Franz Stolzenwald, } \\
\text { wyd. D. Räder, Leipzig [PMO-II-4-351: D oraz KRG] } \\
\text { Die Ordensritter - Ouvertüre, wyd. Robert Rühle, Berlin } \\
\text { [PMO-II-4-583/21] Grosse Melodienreihe / aus der Operette / } \\
\text { Der Tenor der Herzogin [PMO-II-4-583/67] } \\
\text { Romantische Ouvertüre wyd. Richard Birnbach, Berlin } \\
\text { [PMO-II-4-583/18 (pod sygn. PMO-II-4-608: T)] }\end{array}$ \\
\hline $\begin{array}{l}\text { Karl Föderl } \\
(1885-1953)\end{array}$ & $\begin{array}{l}\text { Einmal in der Wochen fall' ich um / Wiener Lied } \\
\text { [PMO-II-4-630/8: T] }\end{array}$ \\
\hline $\begin{array}{l}\text { Gaetano Lama } \\
(1886-1950)\end{array}$ & $\begin{array}{l}\text { Tanz, mein blondes Mädel...! / (Cara piccina!) / } \\
\text { Neapolitanisches Lied, ar. Leopold Weninger, wyd. D. Räder } \\
\text { Verlag, Leipzig [PMO-II-4-587] }\end{array}$ \\
\hline $\begin{array}{l}\text { Otto Witteborn } \\
(1886-1973)\end{array}$ & $\begin{array}{l}\text { Ein Fest im Gnomerich / Ballett-Suite op. 28, wyd. Ed. Bobe } \\
\text { i G. Bock, Berlin [PMO-II-4-583/3] }\end{array}$ \\
\hline $\begin{array}{l}\text { Herms Niel } \\
(1888-1954)\end{array}$ & $\begin{array}{l}\text { Matrosenlied / Marschlied [PMO-II-4-630/12: T] } \\
\text { Wir sind Kameraden / Marschlied [PMO-II-4-630/10: T] }\end{array}$ \\
\hline $\begin{array}{l}\text { Hermann Krome } \\
(1888-1955)\end{array}$ & $\begin{array}{l}\text { Die Mühle im Neckartal / Idyll, wyd. Richard Birnbach, Berlin } \\
\text { [PMO-II-4-583/47] } \\
\text { Frühlig in der Heimat / Walzer, wyd. Richard Birnbach, Berlin } \\
\text { [PMO-II-4-583/48] } \\
\text { Heidelberger Zecher / Walzer, wyd. Richard Birnbach, Berlin } \\
\text { [PMO-II-4-583/46] }\end{array}$ \\
\hline $\begin{array}{l}\text { Ludwig Siede } \\
(1888-1956)\end{array}$ & $\begin{array}{l}\text { Vielliebchen / Intermezzo grazioso. / op. 80, } \\
\text { wyd. Anton J. Benjamin, Leipzig [PMO-II-4-615] } \\
\text { Chinesische Strassenserenade, wyd. Karl Stemmler Verlag, } \\
\text { Leipzig [PMO-II-4-358] } \\
\text { Die Puppenparade / Charakterstück / op. 146, wyd. Karl } \\
\text { Stemmler Verlag, Leipzig [PMO-II-4-630/9 } \\
\text { (pod sygn. PMO-II-4-630/13: T)] } \\
\text { Herbstgedanken / Walzer-Intermezzo. / op. 148, } \\
\text { wyd. Anton J. Benjamin, Hamburg [PMO-II-4-608] }\end{array}$ \\
\hline $\begin{array}{l}\text { Carl Robrecht } \\
(1888-1961)\end{array}$ & $\begin{array}{l}\text { Niagara / Piano-Novelty, wyd. Bosworth and Co., Bruxelles } \\
\text { [PMO-II-4-583/68] }\end{array}$ \\
\hline
\end{tabular}




\begin{tabular}{|c|c|}
\hline $\begin{array}{l}\text { Hans Ludwig } \\
\text { Kormann } \\
\text { (1889-?) }\end{array}$ & $\begin{array}{l}\text { Groteske, wyd. Maximilian Müller Musikverlag, Berlin } \\
\text { [PMO-II-4-583/55] }\end{array}$ \\
\hline $\begin{array}{l}\text { Willi Engel- } \\
\text {-Berger } \\
(1890-1946)\end{array}$ & $\begin{array}{l}\text { Mein Wellensittich Foxtrot Gesangs-Terzett, ar. Adolf } \\
\text { Steimel, wyd. Monopol Liederverlag GmbH., Berlin } \\
\text { [PMO-II-4-371: D oraz KRG] }\end{array}$ \\
\hline $\begin{array}{l}\text { Edmund Nick } \\
(1891-1974)\end{array}$ & $\begin{array}{l}\text { Liebeswalzer aus dem Cine-Allianz-Film „Sechs Tage } \\
\text { Heimaturlaub”, ar. Franz Stolzenwald, wyd. Musikverlag Hans } \\
\text { Sikorski, Leipzig [PMO-II-4-583/62] } \\
\text { Wir sind zwei gute Kameraden / Marschlied } \\
\text { [PMO-II-4-630/17: T] }\end{array}$ \\
\hline $\begin{array}{l}\text { Hanns Löhr } \\
\text { (1892-1982) }\end{array}$ & $\begin{array}{l}\text { Zauber der Wachau / Grosser Walzer, wyd. Verlag von Julius } \\
\text { Bauer, Braunschweig [PMO-II-4-583/26] } \\
\text { Walc / W pięknej dolinie Isary [PMO-II-4-583/76: T] }\end{array}$ \\
\hline $\begin{array}{l}\text { Heinrich Strecker } \\
(1893-1981)\end{array}$ & $\begin{array}{l}\text { Äennchen von Tharau / Grosses Potpourri aus der Sinspiel- } \\
\text {-Operette, wyd. Wiener Boheme GmbH., Berlin } \\
\text { [PMO-II-4-583/65 (pod sygn. PMO-II-4-583/65: T)] } \\
\text { Sing mir das Lied noch Einmal / Langsam Walzer, ar. Oskar } \\
\text { Wagner, wyd. Musikverlag Adolf Robitschek, Leipzig } \\
\text { [PMO-II-4-393: D oraz KRG] }\end{array}$ \\
\hline $\begin{array}{l}\text { Viktor Hruby } \\
(1894-1978)\end{array}$ & $\begin{array}{l}\text { Ein Jahrmarkt im Dorie, wyd. Edition Scala, Wien-Berlin - } \\
\text { Leipzig [PMO-II-4-583/59] }\end{array}$ \\
\hline $\begin{array}{l}\text { Willy Schmidt- } \\
\text {-Gentner } \\
(1894-1964)\end{array}$ & $\begin{array}{l}\text { Ich bin heute ja so verliebt / Lied und langsamer / aus dem } \\
\text { Willy Forst-Film der Wien-Film „Operette”, wyd. Cineton } \\
\text { Verlag GmbH., Berlin [PMO-II-4-395] }\end{array}$ \\
\hline $\begin{array}{l}\text { Nico Dostal } \\
(1895-1981)\end{array}$ & $\begin{array}{l}\text { Ein Besuch / Ein Folge seiner beliebsten Melodien, } \\
\text { ar. Richard Etlinger, wyd. Dreima, Wiesbaden [PMO-II-4-614] }\end{array}$ \\
\hline $\begin{array}{l}\text { Robert Küssel } \\
(1895-1970)\end{array}$ & $\begin{array}{l}\text { Frühlingsträume, wyd. Verlag Goldregen, Berlin } \\
\text { [PMO-II-4-612] }\end{array}$ \\
\hline $\begin{array}{l}\text { Jakob Christ } \\
(1895-1974)\end{array}$ & $\begin{array}{l}\text { Mit Sing - Sang und Kling - Klang Ein neues Soldatenlied, } \\
\text { ar. Bruno Hartmann, wyd. Rud. Erdmann Co., Leipzig } \\
\text { [PMO-II-4-352 D oraz KRG] }\end{array}$ \\
\hline $\begin{array}{l}\text { Wilhelm } \\
\text { Ernst Gabriel } \\
\text { [pseud. Wiga] } \\
\text { (1897-1964) }\end{array}$ & $\begin{array}{l}\text { Ein Lied für dich allein, Lied und langsam Walzer, ar. Horst } \\
\text { Kundritzki, wyd. Edition Gabriel, Wilhelm Gabriel Verlag für } \\
\text { moderne Tanz und Unterhaltungmusik, Berlin [PMO-II-4-385] }\end{array}$ \\
\hline $\begin{array}{l}\text { Will Meisel } \\
(1897-1967)\end{array}$ & $\begin{array}{l}\text { Die Frau im Spiegel Grosses Potpourri aus der gleichnami- } \\
\text { gen Lustspiel-Operette, ar. Franz Stolzenwald } \\
\text { [PMO-II-4-583/53] }\end{array}$ \\
\hline
\end{tabular}




\begin{tabular}{|c|c|}
\hline $\begin{array}{l}\text { Bruno Bartsch } \\
(1898-1980)\end{array}$ & $\begin{array}{l}\text { Flitterwochen / Intermezzo, ar. Adolf Steimel, wyd. Erich } \\
\text { Paftänier, Leipzig [PMO-II-4-583/42 } \\
\text { (pod sygn. PMO-II-4-595: KRG)] }\end{array}$ \\
\hline $\begin{array}{l}\text { Reiny Roland } \\
(1898-1991)\end{array}$ & $\begin{array}{l}\text { Zum } 5 \text { Uhr Tee, Melodienfolge aus beliebten Tonfilm } \\
\text { und Tanzschlagern. Ausgabe für Salon-Orchester } \\
\text { Saxofonstimmen, wyd. Dr Hans Sikorski, Leipzig } \\
\text { [PMO-II-4-190/1-15 9 (pod sygn. PMO-II-4-192: KRG)] }\end{array}$ \\
\hline $\begin{array}{l}\text { Giulio de Micheli } \\
\text { (1899-1940) }\end{array}$ & $\begin{array}{l}\text { Küsse im Dunkeln / Serenata op. 33, wyd. Anthon } \\
\text { J. Benjamin, Leipzig [PMO-II-4-630/13] } \\
\text { Herbstlied op. 64, ar. Leopold Weninger, wyd. D. Räder } \\
\text { Verlag, Leipzig [PMO-II-4-583/31] } \\
\text { Suite di Danze / a) Orientalischer Tanz b) Spanischer } \\
\text { Tanz c) Burlesker Tanz op. 123, wyd. Erich Plessow and Co. } \\
\text { Kommanditgeselschaft, Berlin [PMO-II-4-583/10] }\end{array}$ \\
\hline $\begin{array}{l}\text { Pierre Blaauw } \\
(1899-1943)\end{array}$ & $\begin{array}{l}\text { Die spieluhr / Glocken-Intermezzo, ar. E. Heansch, } \\
\text { wyd Bosworth \& Co., Köln-Wien [PMO-II-4-606 } \\
\text { (pod sygn. PMO-II-4-606: T)] }\end{array}$ \\
\hline $\begin{array}{l}\text { Erich Plessow } \\
(1899-1977)\end{array}$ & $\begin{array}{l}\text { Ich suche eine Freundin für die Ferien / Foxtrot, } \\
\text { ar. Franz Stolzenwald, wyd. Edition Standars, Musik und } \\
\text { Bühnenverlag, Erich Plessow \& Co., Berlin [PMO-II-4-394] }\end{array}$ \\
\hline $\begin{array}{l}\text { Fred Raymond } \\
\text { (1900-1954) }\end{array}$ & $\begin{array}{l}\text { Komm trink und lach am Rhein / Walzer-lied } \\
\text { [PMO-II-4-630/9: T] } \\
\text { Für mich gibts nur eine Frau... / Foxtrot [PMO-II-4-365: KRG] }\end{array}$ \\
\hline $\begin{array}{l}\text { Heinz Munkel } \\
\text { (1900-1961) }\end{array}$ & $\begin{array}{l}\text { Das Hohnsteiner Kasperle / Charakterstück, ar. Bernh. Egg, } \\
\text { wyd. N. Simrock, Leipzig [PMO-II-4-603] }\end{array}$ \\
\hline $\begin{array}{l}\text { Willy Richartz } \\
(1900-1972)\end{array}$ & $\begin{array}{l}\text { Traum - Melodien / Walzer, ar. L. Kletsch, wyd. Paul Paasch } \\
\text { „Florida“ Musikverlag, Berlin [PMO-II-4-583/37] } \\
\text { Bayerische G'schichten / Walzer, wyd. Musikverlag „Florida”, } \\
\text { Berlin. [PMO-II-4-630/10 (pod sygn. PMO-II-4-603: T)] }\end{array}$ \\
\hline $\begin{array}{l}\text { Ernst Fischer } \\
(1900-1975)\end{array}$ & $\begin{array}{l}\text { Bummel am Abend Intermezzo, wyd. Heinrichshofen's } \\
\text { Verlag, Magdeburg [PMO-II-4-583/5] }\end{array}$ \\
\hline $\begin{array}{l}\text { Walther Noack } \\
(1900-1992)\end{array}$ & $\begin{array}{l}\text { Einzung des Schneekönigs / Charakterstück op. 17, } \\
\text { wyd. W. Huhn, Musikalien-Verlag, Lüdenscheid } \\
\text { [PMO-II-4-630/2, PMO-II-4-583/35] }\end{array}$ \\
\hline $\begin{array}{l}\text { Werner } \\
\text { Bochmann } \\
(1900-1993)\end{array}$ & $\begin{array}{l}\text { In einem weissen Mahnfeld / Langsamer Walzer, ar. Friedrich } \\
\text { Schröder [PMO-II-4-356: D oraz KRG] }\end{array}$ \\
\hline $\begin{array}{l}\text { Billy } \\
\text { Bartholomew } \\
(1901-1972)\end{array}$ & Jeden Abend Foxtrot [PMO-II-4-362: KRG] \\
\hline
\end{tabular}




\begin{tabular}{|c|c|}
\hline $\begin{array}{l}\text { Walter Jäger } \\
(1901-1975)\end{array}$ & $\begin{array}{l}\text { Kleine Parade / Intermezzo, ar. Schönian, wyd. Taunus- } \\
\text {-Verlag, Frankfurt a. M. [PMO-II-4-583/64] } \\
\text { Wenn kleine Mädchen von der Liebe träumen Melodie } \\
\text { Foxtrot, ar. Helmut Gardens, wyd. Taunus Verlag H.L. Grahl, } \\
\text { Frankfurt a. M. [PMO-II-4-368] } \\
\text { Du sollst um mich nicht weinen / Langs. Walzer } \\
\text { [PMO-II-4-583/52: T] }\end{array}$ \\
\hline $\begin{array}{l}\text { Josef M. Kratky } \\
(1901-1975)\end{array}$ & $\begin{array}{l}\text { Hinter der Letzten Laterne... Lied und langsamer, ar. Josef } \\
\text { Kurz, wyd. Hans Kratky Musikverlag, Wien-Leipzig } \\
\text { [PMO-II-4-390] }\end{array}$ \\
\hline $\begin{array}{l}\text { Gerhard Mohr } \\
\text { (1901-1979) }\end{array}$ & $\begin{array}{l}\text { Regenbogen-Walzer / Konzertwalzer, wyd. D. Räder, Leipzig } \\
\text { [PMO-II-4-604] } \\
\text { Stunden - die man nie vergessen kann / Lied und lang- } \\
\text { samer Walzer, wyd. Dreikland Verlag A.G., Berlin } \\
\text { [PMO-II-4-384] } \\
\text { Du hast den schönsten Mund / Monika-Luise! Tango, } \\
\text { wyd. Musikverlag Peter Schaeffers, Berlin } \\
\text { [PMO-II-4-372: D oraz KRG] }\end{array}$ \\
\hline $\begin{array}{l}\text { Zdeněk Hůla } \\
\text { [pseud. Zdenko } \\
\text { Bayer] } \\
(1901-1986)\end{array}$ & $\begin{array}{l}\text { Vojáček / charakteristická skladba / Der kleine soldat / } \\
\text { Charakterstück, ar. B. Leopold, wyd. Edition Continental, } \\
\text { Praha [PMO-II-4-610] }\end{array}$ \\
\hline $\begin{array}{l}\text { Jupp Schmitz } \\
(1901-1991)\end{array}$ & $\begin{array}{l}\text { Denn ich bin ein rheinisher Junge Foxtrot, ar. Adolf Steimel, } \\
\text { wyd. Jupp Schmitz Verlag, Köln [PMO-II-4-378] }\end{array}$ \\
\hline $\begin{array}{l}\text { Frank Fux [Fox] } \\
(1902-1965)\end{array}$ & $\begin{array}{l}\text { Weisst du noch / Tango Serenade aus dem Algefa-Film - } \\
\text { "Aufruhr im Damenstift", ar. Gerhard Mohr, wyd. Musikverlag } \\
\text { Peter Schaeffers, Berlin [PMO-II-4-392] }\end{array}$ \\
\hline $\begin{array}{l}\text { Eldo di Lazzaro } \\
\text { (1902-1968) }\end{array}$ & $\begin{array}{l}\text { Am Abend auf der Heide Foxtrot, ar. Franz Stolzenwald, } \\
\text { wyd. Edizioni Musicali „Emi” Milano, Galleria del Corso } \\
\text { [PMO-II-4-382: D oraz KRG] }\end{array}$ \\
\hline
\end{tabular}




\begin{tabular}{|l|l|}
\hline $\begin{array}{l}\text { Josef Rixner } \\
\text { (1902-1973) }\end{array}$ & $\begin{array}{l}\text { Der arme Jonathan / Potpourri aus der Operette, } \\
\text { ar. Millöker-Rixner, wyd. Bühnen und Musikalienverlag, Josef } \\
\text { Weinberger, Berlin [PMO-II-4-583/50] } \\
\text { Bagatelle-Ouverture nr 27 [PMO-II-4-182] } \\
\text { Tanz der Maske / Serenade und Capriccio, wyd. Kawi-Verlag } \\
\text { Karl Wilke, Berlin-Wilmersdorf [PMO-II-4-583/25 } \\
\text { (pod sygn. PMO-II-4-594: KRG)] } \\
\text { Spiel im Wind, wyd. Musikverlag Matth. Hohner A.G., Berlin } \\
\text { [PMO-II-4-583/34] } \\
\text { Morgen im Mai [PMO-II-4-583/34: ZW] } \\
\text { Spitzbub [PMO-II-4-630/16: T] }\end{array}$ \\
\hline $\begin{array}{l}\text { Fritz Domina } \\
\text { (1902-1975) }\end{array}$ & $\begin{array}{l}\text { Lustiger Matrosen-tanz, wyd. Harth Verlag, Erich Pastänier, } \\
\text { Leipzig [PMO-II-4-359] }\end{array}$ \\
\hline $\begin{array}{l}\text { Heinrich Steiner } \\
\text { (1903-1982) }\end{array}$ & $\begin{array}{l}\text { Serenata appasionata, wyd.,,Florida" Musikverlag und } \\
\text { Sortiment, Paul Paasch, Berlin [PMO-II-4-583/13] }\end{array}$ \\
\hline $\begin{array}{l}\text { Ludwig } \\
\text { Schmidseder } \\
\text { (1904-1971) }\end{array}$ & $\begin{array}{l}\text { Ich wollt' ich hätt' / im Wirtshaus gleich mein Bett! / } \\
\text { Wienerlied, ar. Franz Stolzenwald, wyd. Musikverlag Peter } \\
\text { Schaeffers, Berlin [PMO-II-4-591] } \\
\text { Potpourri / Melodie der Nacht [PMO-II-4-604: ZW] }\end{array}$ \\
\hline $\begin{array}{l}\text { Walter } \\
\text { Baumgartner } \\
\text { (1904-1997) }\end{array}$ & $\begin{array}{l}\text { Noch sind die Tage der Rosen / Lied, ar. Josef Németi, } \\
\text { wyd. D. Räder, Leipzig [PMO-II-4-583/63] }\end{array}$ \\
\hline $\begin{array}{l}\text { Hans Otten } \\
\text { (1905-1942) }\end{array}$ & $\begin{array}{l}\text { Du kannst von mir alles haben / Schunkelwalzer } \\
\text { [PMO-II-4-583/70: T] }\end{array}$ \\
\hline $\begin{array}{l}\text { Mátyás György } \\
\text { Seiber } \\
\text { [G.S. Mathis] } \\
\text { (1905-1960) }\end{array}$ & $\begin{array}{l}\text { Fesival at Sevilla / Spanish Rhapsody, wyd. Schott - Co. Ltd., } \\
\text { London [PMO-II-4-583/7] }\end{array}$ \\
\hline $\begin{array}{l}\text { Michael Jary } \\
\text { (1906-1988) }\end{array}$ & $\begin{array}{l}\text { Roter Mohn Tango aus dem Algefa-Film der Terra } \\
\text { Filmkunst / 'Schwarzfahrt ins Glück", wyd. Wiener Boheme } \\
\text { Verlag GmbH., Berlin-Wien [PMO-II-4-366] }\end{array}$ \\
\hline
\end{tabular}




\begin{tabular}{|c|c|}
\hline $\begin{array}{l}\text { Gerhard Winkler } \\
\text { (1906-1977) }\end{array}$ & $\begin{array}{l}\text { Unter blühenden Orangen / Ständchen, wyd. Apollo Verlag, } \\
\text { Berlin [PMO-II-4-630/11] } \\
\text { Japanisches Teehaus / Intermezzo, wyd. Musikverlag Paul } \\
\text { Schmidt, Berlin [PMO-II-4-590] } \\
\text { Im Herbst / Suite in } 3 \text { Sätzen / 1. Fallende Blätter / } \\
\text { 2. Herbstlied / 3. Parforce-Jagd [PMO-II-4-583/72] Der } \\
\text { kleine Postillon / Tanz - Intrmezzo, ar. Helmut Gardens, } \\
\text { wyd. Edition Wilhelm Gabriel Verlag, Berlin } \\
\text { [PMO-II-4-396: D oraz KRG] } \\
\text { Klein Sennerin / Lied und Tango, wyd. Edition } \\
\text { Gabriel, Wilhelm Gabriel Verlag für moderne Tanz und } \\
\text { Unterhaltungmusik, Berlin [PMO-II-4-380: D oraz KRG] } \\
\text { Georgine / Foxtrot [PMO-II-4-610: T] }\end{array}$ \\
\hline $\begin{array}{l}\text { Michael Jary } \\
\text { [Maksymilian } \\
\text { Michał Jarczyk] } \\
\text { (1906-1988) }\end{array}$ & Der Onkel Jonathan / Foxtrot [PMO-II-4-583/59: T] \\
\hline $\begin{array}{l}\text { Erich Börschel } \\
\text { (1907-1988) }\end{array}$ & Tanz der Geishas / Foxtrot-Intermezzo [PMO-II-4-583/72: T] \\
\hline $\begin{array}{l}\text { Gino Redi } \\
\text { [P.G. Redi] } \\
(1908-1962)\end{array}$ & $\begin{array}{l}\text { Die Phantastische Nacht / Tango Bolero, wyd. Redi S.A. } \\
\text { Edizioni Musicali Milano, Galleria dei Corso } \\
\text { [PMO-II-4-363: D oraz KRG] }\end{array}$ \\
\hline $\begin{array}{l}\text { Franz Grothe } \\
(1908-1982)\end{array}$ & $\begin{array}{l}\text { Lied der Nachtigall / aus dem Film der Terra Filmkunst } \\
\text { GmbH. / „Die schwedische Nachtigall”, ar. Walter Borchert, } \\
\text { wyd. Wiener Boheme Verlag, GmbH., Berlin } \\
\text { [PMO-II-4-583/79 (pod sygn. PMO-II-4-583/79: T)] } \\
\text { Postillion Lied [PMO-II-4-583/79: T] } \\
\text { Grüss mir die Berolina - Berliner Lied [PMO-II-4-604: T] } \\
\text { Wenn unser Berlin ver dunkelt ist - Marschfoxtrot } \\
\text { [PMO-II-4-604: T] }\end{array}$ \\
\hline $\begin{array}{l}\text { Alberto Semprini } \\
(1908-1990)\end{array}$ & $\begin{array}{l}\text { Leila Rhythmischer Foxtrot [PMO-II-4-376: D oraz KRG } \\
\text { (pod sygn. PMO-II-4-608: T)] }\end{array}$ \\
\hline $\begin{array}{l}\text { Herbert Küster } \\
(1909-1986)\end{array}$ & $\begin{array}{l}\text { Teerose / Lyrisches Intermezzo, ar. Hartwig von Platen, } \\
\text { wyd. Richard Birnbach, Berlin [PMO-II-4-630/15] }\end{array}$ \\
\hline $\begin{array}{l}\text { Edmund } \\
\text { Kötscher } \\
(1909-1990)\end{array}$ & $\begin{array}{l}\text { Wilde Rosen / Walzer, ar. Horst Kudritzki, wyd. Richard } \\
\text { Birnbach, Berlin [PMO-II-4-583/41] } \\
\text { Wenn die Lichter wieder scheinen / Foxtrot } \\
\text { [PMO-II-4-583/67: T] } \\
\text { Dorfmusikanten [PMO-II-4-396: ZW] }\end{array}$ \\
\hline $\begin{array}{l}\text { Hans Busch } \\
(1909-1996)\end{array}$ & $\begin{array}{l}\text { Dideldideldum, Dideldideldei / Foxtrot, ar. Horst Kudritzki, } \\
\text { wyd. Edition Gabriel, Berlin [PMO-II-4-375: D oraz KRG] }\end{array}$ \\
\hline
\end{tabular}




\begin{tabular}{|c|c|}
\hline $\begin{array}{l}\text { Friedrich } \\
\text { Schröder } \\
(1910-1972)\end{array}$ & $\begin{array}{l}\text { Ja, so war es zu Grossmutters Zeiten / Lied und Tango, } \\
\text { wyd. Alfred Klabunde Musikverlag, Berlin [PMO-II-4-381] } \\
\text { Ein Glück, dass man sich so verlieben kann! / Lied und } \\
\text { foxtrot, wyd. Musikverlag Peter Schaeffers, Berlin. Na karcie } \\
\text { katalogowej napisano, iż jest to aria z operetki Heinza } \\
\text { Hautschke pt. Hochzeitsnacht im Paradis. } \\
\text { [PMO-II-4-353: D oraz KRG (pod sygn. PMO-II-4-583/64: T)] }\end{array}$ \\
\hline $\begin{array}{l}\text { Nino Casiroli } \\
(1910-1975)\end{array}$ & $\begin{array}{l}\text { Nie war Musik so schön / Melodie Foxtrot } \\
\text { [PMO-II-4-364: D oraz KRG (pod sygn. PMO-II-4-583/68: T)] }\end{array}$ \\
\hline $\begin{array}{l}\text { Horst Kudritzki } \\
(1911-1970)\end{array}$ & $\begin{array}{l}\text { Von } 8 \text { bis um 8! Melodie Foxstrot, wyd. Monopol-Lieder } \\
\text { Verlag GmbH. [PMO-II-4-361: D oraz KRG] }\end{array}$ \\
\hline $\begin{array}{l}\text { Ralph Maria } \\
\text { Siegel } \\
(1911-1972)\end{array}$ & $\begin{array}{l}\text { In Freundschaft / Tango und Konzertlied, ar. Franz } \\
\text { Stolzenwald, wyd. Musikverlag Peter Schaeffers, Berlin } \\
\text { [PMO-II-4-391: D oraz KRG] } \\
\text { Briefe, die dich nie erreichten... Lied und Melodie-Foxtrot, } \\
\text { ar. Adolf Steimel, wyd. Albert Bennefeld Musikverlag, Berlin } \\
\text { [PMO-II-4-369] } \\
\text { Sing ein Lied - wenn du mal traurig bist Foxtrot, wyd. Albert } \\
\text { Bennefeld Musikverlag, Berlin [PMO-II-4-370] } \\
\text { Unter ser roten Laterne von St. Pauli Tangolied, } \\
\text { wyd. Musikverlag Peter Schaeffers, Berlin } \\
\text { [PMO-II-4-372: D oraz KRG] } \\
\text { Kleiner Hampelmann / Foxtrot-Intermezzo } \\
\text { [PMO-II-4-583/65: T] } \\
\text { Heut wird ein Märchen wahr / Tango [PMO-II-4-606: T] }\end{array}$ \\
\hline $\begin{array}{l}\text { Cosimo Di Ceglie } \\
(1913-1980)\end{array}$ & Oh Marie, oh Marie! / Foxtrot [PMO-II-4-583/62: T] \\
\hline $\begin{array}{l}\text { Lotar Olias } \\
(1913-1990)\end{array}$ & $\begin{array}{l}\text { Die nacht sieht mich so seltsam an mit ihrer Sternen / Lied } \\
\text { und langsamer Walzer, ar. Franz Stolzenwald, wyd. Teo-Ton } \\
\text { Verlag, Berlin [PMO-II-4-387] } \\
\text { Foxtrot auf dem Puppenklavier / Foxtrott-Intermezzo, } \\
\text { ar. Walter Meissner, wyd. Teo-Ton-Verlag, Berlin } \\
\text { [PMO-II-4-598: D oraz KRG] }\end{array}$ \\
\hline $\begin{array}{l}\text { Franz Josef } \\
\text { Breuer } \\
\text { (1914-1996) }\end{array}$ & $\begin{array}{l}\text { Weit ist der Weg in die Heimat / Lied und Tango, ar. Franz } \\
\text { Stolzenwald, wyd. W. Ehrler \& Co, Leipzig [PMO-II-4-374] }\end{array}$ \\
\hline $\begin{array}{l}\text { Børge Friis } \\
(1914-1998)\end{array}$ & Jedertanzt / Foxtrot [PMO-II-4-583/53: T] \\
\hline $\begin{array}{l}\text { Karl Bette } \\
(1916-2006)\end{array}$ & $\begin{array}{l}\text { Foxtrot Bitte, bitte, lieber Geiger ... mach Musik für mich!, } \\
\text { wyd. Karl Bette (brak miejsca wydania) [PMO-II-4-373] }\end{array}$ \\
\hline
\end{tabular}




\section{b. Dzieła twórców trudnych do zidentyfikowania}

(w porządku alfabetycznym)

\begin{tabular}{|c|c|}
\hline $\begin{array}{l}\text { Friedrich Wilhelm } \\
\text { Haarhaus }\end{array}$ & $\begin{array}{l}\text { Geisterzug um Mitternacht / Charakterstück / op. 48, } \\
\text { ar. J. Engleman, wyd. Bosworth und Co., Bruxelles } \\
\text { [PMO-II-4-583/24] }\end{array}$ \\
\hline B. Leopold & $\begin{array}{l}\text { Plavovláska / Die blond Puppe / Intermezzo / op. 49, } \\
\text { wyd. Edition Continental, Praha } \\
\text { [PMO-II-4-617] } \\
\text { Galanterie / Walzer op. 93, wyd. Edition Continental, Praha } \\
\text { [PMO-II-4-601] }\end{array}$ \\
\hline Charlotte Baerenz & $\begin{array}{l}\text { Bei Kerzenlicht [PMO-II-4-360: KRG } \\
\text { (pod sygn. PMO-II-4-583/63: T)] }\end{array}$ \\
\hline Willy Baldamus & $\begin{array}{l}\text { Triumph der Liebe Marsch [PMO-II-4-384: ZW] } \\
\text { Unter Fahnen und Standarten Marsch } \\
{[\mathrm{PMO}-I I-4-384: \mathrm{ZW}]}\end{array}$ \\
\hline Carl Barth & $\begin{array}{l}\text { Nordische Ballade / Konzertstück, } \\
\text { wyd. Musikverlag Math. Hohner, Berlin-Wien } \\
\text { [PMO-II-4-630/12] }\end{array}$ \\
\hline Bruno Bauer & $\begin{array}{l}\text { Wienerisch im 3/4 Takt / Walzer, wyd. Musikverlag Adolf } \\
\text { Rabitschek, Wien-Leipzig-Berlin } \\
\text { [PMO-II-4-630/6] }\end{array}$ \\
\hline Lüdwig Bernaüer & $\begin{array}{l}\text { Wenn es wo noch Märchen gibt... / Lied und langsamer } \\
\text { Walzer, ar. Josef Kurz, wyd. Hans Kratky } \\
\text { Musikverlag Wien-Leipzig [PMO-II-4-390] }\end{array}$ \\
\hline Walter Borchert & $\begin{array}{l}\text { Wenn ich rote Rosen seh'/ Lied, wyd. Wiener Boheme } \\
\text { Verlag GmbH., Berlin [PMO-II-4-583/78], } \\
\text { wyd. C.F. Peters, Leipzig [PMO-II-4-630/24] }\end{array}$ \\
\hline Fred Caphat & $\begin{array}{l}\text { Eccenctric Foxtrott / Novelty Piano-Solo with Orchestra, } \\
\text { wyd. Suppan's Verlag, Dusseldorf [PMO-II-4-613] }\end{array}$ \\
\hline Hans Carreño & $\begin{array}{l}\text { Kleine Ironien / Caprice / Lied, wyd. Paul Paasch „Florida” } \\
\text { Musikverlag, Berlin [PMO-II-4-583/66, PMO-II-4-592] } \\
\text { In einem küheln Grunde / Lied, wyd. Paul Paasch „Florida”, } \\
\text { Berlin [PMO-II-4-592] }\end{array}$ \\
\hline Franz Doello & $\begin{array}{l}\text { Kleine Mitsu (Drüben in meiner Heimat) / Langsam } \\
\text { Walzer, ar. Franz Mück, wyd. Echo Musikverlag GmbH., } \\
\text { Berlin [PMO-II-4-388: D oraz KRG] }\end{array}$ \\
\hline A. Escobar & La Principessa del Valzer [PMO-II-4-583/77] \\
\hline G. Fabiani & Venezia Marsch [PMO-II-4-607: ZW] \\
\hline
\end{tabular}




\begin{tabular}{|c|c|}
\hline Fritz German & $\begin{array}{l}\text { Ather Wellen! / (Onde Eteree) / Wiener Walzer No. 2, } \\
\text { wyd. Isetem - Icilio Sterbini, Roma [PMO-II-4-630/16, } \\
\text { PMO-II-4-583/77 (pod sygn. PMO-II-4-600: T)] }\end{array}$ \\
\hline G. Groitzsch & $\begin{array}{l}\text { Der Jongleur / Excentric Novelette, wyd. Bosworth } \\
\text { u. Co., Leipzig [PMO-II-4-583/44] }\end{array}$ \\
\hline B. Hauer & Wienerisch im 3/4 Takt / Walzer [PMO-II-4-630/6: T] \\
\hline Carl Hauschild & Frohsinn / Marsch [PMO-II-4-630/11: T] \\
\hline $\begin{array}{l}\text { Hans A. Heumann } \\
\text { [Richard Werner } \\
\text { Heymann (?)] }\end{array}$ & Rhapsodie Nr 1 [PMO-II-4-600: KRG] \\
\hline $\begin{array}{l}\text { L. Hildebrandt- } \\
\text {-Leuschner }\end{array}$ & $\begin{array}{l}\text { Alt-Berlin / im Walzertakt / Walzer-Potpourri } \\
\text { [PMO-II-4-630/23: T] }\end{array}$ \\
\hline Josef Holetschek & $\begin{array}{l}\text { Fidele Bauern Polka, wyd. P. Raasch, Musikverlag, } \\
\text { Berlin [PMO-II-4-354: D oraz KRG] }\end{array}$ \\
\hline Bobby Hönn & $\begin{array}{l}\text { Mein Glück / Langsamer Walzer, wyd. Eden Musikverlag } \\
\text { Glauchau Inh. Robert Hönn (brak miejsca wydania) } \\
\text { [PMO-II-4-386] }\end{array}$ \\
\hline $\begin{array}{l}\text { Michaił J. Ippolitow- } \\
\text {-Iwanow }\end{array}$ & Suita / II część / Szkice kaukaskie [PMO-II-4-583/77: T] \\
\hline Wendelin Kopetzky & Egerländer / Marsch [PMO-II-4-630/3: T] \\
\hline F. Kowary & $\begin{array}{l}\text { Wie schön bist du / mein Heimatland / Lied } \\
{[\text { PMO-II-4-630/7: T] }}\end{array}$ \\
\hline R. Kronegger-Muss & Beim Heurigen / Potpourri [PMO-II-4-583/15: T] \\
\hline $\begin{array}{l}\text { (?) Krüger- } \\
\text {-Hanschmann }\end{array}$ & Tausend Wochen / Foxtrot [PMO-II-4-583/54: T; ZW] \\
\hline Georg Lohmann & $\begin{array}{l}\text { Bayrische Polka / Solo für Pousaune, ar. Matthias Perl, } \\
\text { wyd. Friedrich Wilhelm Fröhlich, Berlin } \\
\text { [PMO-II-4-583/36] }\end{array}$ \\
\hline Erich Lutz & $\begin{array}{l}\text { Faschingsgeister / Walzer, ar. Karl Bucholz, wyd. Paul } \\
\text { Paasch „Florida" Musikverlag Sortiment, Berlin } \\
\text { [PMO-II-4-583/51] }\end{array}$ \\
\hline Carl May & $\begin{array}{l}\text { Ouvertüre über Eine Kreutzer Etüde op. 36, } \\
\text { wyd. Albert Schaper, Berlin [PMO-II-4-599] }\end{array}$ \\
\hline Ferry Muhr & $\begin{array}{l}\text { So war's in Wien / Konzertwalzer, wyd. Albert } \\
\text { Bennefeld, Berlin [PMO-II-4-583/80] }\end{array}$ \\
\hline W. Nehl & $\begin{array}{l}\text { Zigeuner Ständchen op. } 32 \text { / Serenade Tzigane / Morceau } \\
\text { characteristique, wyd. Louis Oertel } \\
\text { Musikverlag, Hannover [PMO-II-4-583/2] }\end{array}$ \\
\hline Alfons Plank & $\begin{array}{l}\text { Der kleine Wildfang / Galopp, ar. Leopold Weninger, } \\
\text { wyd. D. Räder, Leipzig [PMO-II-4-583/28, PMO-II-4-588] }\end{array}$ \\
\hline
\end{tabular}


Hubert Szczęśniak, Muzykalia w zbiorach Państwowego...

\begin{tabular}{|c|c|}
\hline $\begin{array}{l}\text { Wladimir } \\
\text { Pogorelow }\end{array}$ & $\begin{array}{l}\text { Ständchen, ar. Bruno Kartmann, wyd. Härth Verlag, Leipzig } \\
\text { [PMO-II-4-583/61] }\end{array}$ \\
\hline $\begin{array}{l}\text { Ferdinand Poliakin } \\
(18 . .-1921)\end{array}$ & $\begin{array}{l}\text { Imitation des petits Tambours F. Poliakin, } \\
\text { wyd. Bosworth u. Co., Leipzig [PMO-II-4-583/29] }\end{array}$ \\
\hline Martin Schönicke & $\begin{array}{l}\text { Feldpost für Annchen / Lied, ar. Gerhard Mohr, } \\
\text { wyd. Arcadia Verlag GmbH., Berlin [PMO-II-4-419] }\end{array}$ \\
\hline Otto Stolzenwald & $\begin{array}{l}\text { Der erste Schritt / Lustiges Intermezzo, } \\
\text { wyd. Dreiklang--Dreimasken Bühen und Musikverlag, } \\
\text { Berlin [PMO-II-4-583/45] }\end{array}$ \\
\hline Rudolf Tichy & Osterreichische Wachtparade [PMO-II-4-393: ZW] \\
\hline Stassi D. Tombulis & $\begin{array}{l}\text { Traum von Haiti / Ein Südsee Tango, ar. Franz Stolzenwald, } \\
\text { wyd. Harth-Verlag Erich Pastänier, Leipzig } \\
\text { [PMO-II-4-350: D oraz KRG (pod sygn. PMO-II-4-583/61: T)] }\end{array}$ \\
\hline $\begin{array}{l}\text { Joska Vidák } \\
\text { [kompozytor } \\
\text { węgierski] }\end{array}$ & $\begin{array}{l}\text { Csibi / Ungarische Geigenpolka, ar. Bruno Hartmann, } \\
\text { wyd. Aug. Cranz GmbH., Leipzig [PMO-II-4-619] }\end{array}$ \\
\hline
\end{tabular}

\section{c. Dzieła niezidentyfikowane oraz kompozycje powstałe po wojnie i przesłane do Działu Zbiorów oświęcimskiego Muzeum}

\begin{tabular}{|c|c|}
\hline $\mathrm{nn}$ & $\begin{array}{l}\text { Die Schönste Zeit des Lebens (Moderato). Materiał nutowy } \\
\text { składa się z } 28 \text { kart przepisanych odręcznie. Na kartach } \\
\text { oznaczonych numerami } 16 \text { i } 20 \text { numer obozowy więźnia } \\
\text { "5665", na kartach } 22 \text { i } 24 \text { numer obozowy "5131" (prawdo- } \\
\text { podobnie przepisane z druku). [PMO-II-4-357] }\end{array}$ \\
\hline $\mathrm{nn}$ & $\begin{array}{l}\text { Ich wollt, ich hätt im Wirtshaus gleich mein Bett! Materiał } \\
\text { nutowy składa się z } 15 \text { kart odręcznie napisanych. } \\
\text { Wszystkie karty opatrzone pieczęcią kapeli. [PMO-II-4-355] }\end{array}$ \\
\hline $\mathrm{nn}$ & $\begin{array}{l}\text { Brak tytułu. Materiał nutowy niekompletny, składający } \\
\text { się z jednej karty zapisanej odręcznie. U góry na } \\
\text { postrzępionym brzegu fragment napisu:,...im Cuwar..... Na } \\
\text { drugiej stronie karty ślad po pieczęci orkiestry obozowej. } \\
\text { [PMO-II-4-193] }\end{array}$ \\
\hline $\mathrm{nn}$ & $\begin{array}{l}\text { Brak tytułu. Materiał nutowy niekompletny. Zachowała się } \\
\text { tylko jedna strona z nutami, pod nimi tekst piosenki } \\
\text { w j. niemieckim. W prawym górnym rogu umieszczony nu- } \\
\text { mer strony: „27", w lewym - napis: „espressivo". W prawym } \\
\text { dolnym rogu widnieje napis: „Musikaliendruckerei E. Leeb, } \\
\text { Wien 20... [PMO-II-4-194] }\end{array}$ \\
\hline
\end{tabular}




\begin{tabular}{|c|c|}
\hline $\begin{array}{l}\text { Karpiński } \\
\text { (? Informacja } \\
\text { w karcie) - } \\
\text { Karol Kurpiński }\end{array}$ & $\begin{array}{l}\text { Uwertura / do op. Leśnicy / z Krunickiej Puszczy / } \\
\text { K. M. / } 944 \text { r. / Auschwitz (?). Materiał nutowy do uwertury - } \\
\text { niekompletny. Rękopis spisany ołówkiem na papierze nuto- } \\
\text { wym. Strony numerowane. Rękopis znajduje się w tekturo- } \\
\text { wej teczce z wypisanym numerem „158”. Wewnątrz teczki } 3 \\
\text { luźne karty: 1) szkic pieśni Daremne żale, 2) szkic nieziden- } \\
\text { tyfikowany, z podpisem „Kip”, 3) szkic utworu symfoniczne- } \\
\text { go Moderato ala Mazur na chór czterogłosowy i orkiestrę } \\
\text { symfoniczną. Materiał nutowy składa się z } 10 \text { kart. Być może } \\
\text { chodzi o próbę odtworzenia fragmentów opery Karola } \\
\text { Kurpińskiego Leśniczy z Kozienieckiej Puszczy. W do- } \\
\text { stępnej literaturze muzycznej nie występuje kompozytor } \\
\text { o nazwisku Karpiński ani dzieło o tytule Leśnicy z Krunickiej } \\
\text { Puszczy, stąd prawdopodobnym tropem wydaje się utwór } \\
\text { Kurpińskiego. [PMO-II-4-306] }\end{array}$ \\
\hline $\begin{array}{l}\text { muzyka: Edmund } \\
\text { Dehnert } \\
\text { tekst: Howard } \\
\text { Poteet }\end{array}$ & $\begin{array}{l}\text { For the Dead Children of Auschwitz. Poem. Zeszyt z nu- } \\
\text { tami i tekstem utworu, przeznaczonego na głos męski } \\
\text { i fortepian. Zawiera } 7 \text { kart napisanych odręcznie, oprawiony } \\
\text { w kartonowe, sztywne, czerwone okładki. Na okładce czar- } \\
\text { ny napis: „FOR THE DEAD CHILDREN OF AUSCHWITZ / POEM } \\
\text { BY G. HOWARD POTEET / MUSIC BY EDMUND DEHNERT”. Do } \\
\text { zeszytu dołączone pismo w języku angielskim podpisane } \\
\text { przez autorów utworu. Na pierwszej stronie wskazówki } \\
\text { wykonawcze. Kompozycja powojenna. } \\
\text { [PMO-II-4-345] }\end{array}$ \\
\hline Wasylij Kjandski & $\begin{array}{l}\text { Ballada rosyjska „Botinki w Oswencime” („Buty } \\
\text { w Oświęcimiu"). W prawym górnym rogu nazwisko kom- } \\
\text { pozytora muzyki Wasylija Kjandskiego oraz autora słów } \\
\text { W. Palczynskaite. Do nut dołączony został maszynopis } \\
\text { z tekstem ballady. Materiał składa się z dwóch } \\
\text { egz. 4-stronicowych nut, sporządzonych odręcznie. } \\
\text { Kompozycja powojenna. [PMO-II-4-197/1,2] }\end{array}$ \\
\hline $\begin{array}{l}\text { muz. Gracjan } \\
\text { Guziński Jasio" / } \\
\text { sł. Konstanty } \\
\text { Świerk }\end{array}$ & 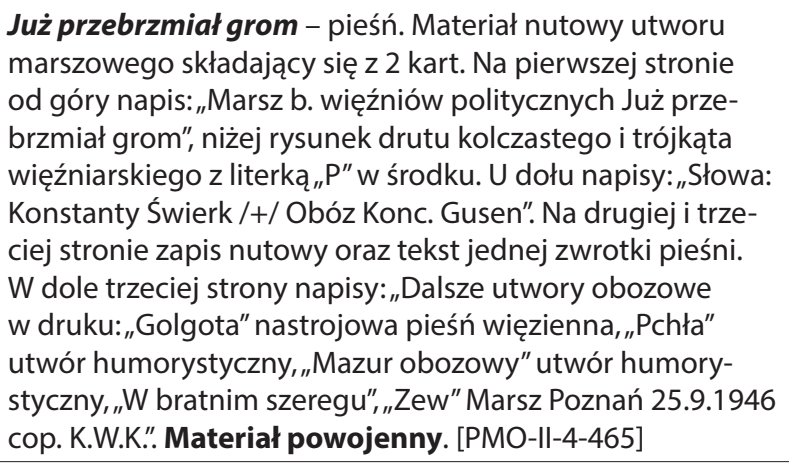 \\
\hline $\mathrm{nn}$ & Deutsche / Marsch-Perle / Potpourri [PMO-II-4-583/61: ZW] \\
\hline
\end{tabular}




\section{Bibliografia}

About the Writers. Dr Guido Jochen Fackler, [w:] Music and the Holocaust, strona internetowa organizacji World ORT Holocaust Music, [online] http://holocaustmusic.ort.org/about-us/about-the-writerso/ [dostęp: 11.06.2016].

Archiwum PMA-B, Zespół Oświadczenia, t. 73, k. 86-88, relacja Bolesława Majcherczyka.

Archiwum PMA-B, Zespół Oświadczenia, t. 76, k. 204-205, relacja Henryka Króla.

Archiwum PMA-B, Zespół Oświadczenia, t. 84, k. 112-116, relacja Wiktora Zielińskiego.

Archiwum PMA-B, Zespół Oświadczenia, t. 96, k. 16-21, relacja Franciszka Stryja.

Archiwum PMA-B, Zespół Oświadczenia, t. 116, k. 78-82, relacja Jerzego Strzeleckiego.

Auschwitz 1940-1945. Węzłowe zagadnienia z dziejów obozu, red. W. Długoborski, F. Piper, Oświęcim 1995.

[b.a.], Anita Lasker-Wallfisch, [w:] Music and the Holocaust, [online] http://holocaustmusic.ort.org/places/camps/death-camps/birkenau /anita-lasker-wallfisch/ [dostęp: 28.05.2016].

[b.a.], Fania Fénelon, [w:] Music and the Holocaust, [online:] http:// holocaustmusic.ort.org/places/camps/death-camps/birkenau/fenelonfania/ [dostęp: 28.05.2016].

[b.a.], Hans Ailbout, [w:] HeBu. Musikverlag GmbH, [online] https:// www.munzinger.de/search/go/document.jsp?id=00000006582 [dostęp: 31.03.2017].

[b.a.], Josef Rixner, [w:], Munzinger Online. Biographien, [online] https:// www.munzinger.de/search/go/document.jsp?id=00000006582 [dostęp: 31.03.2017].

[b.a.], Uroczyste posiedzenie z okazji 68. rocznicy oswobodzenia obozu Auschwitz-Birkenau, reportaż z przekazania Portretu Chopina Mieczysława Kościelniaka do zbiorów Muzeum UJ, [online] http:// www.uj.edu.pl/wiadomosci/archiwum-foto-wideo/-/journal _content/56_INSTANCE_s2jraYnlcxoO/10172/13276214 [dostęp: 21.06.2016].

Bilica K, Laks, Szymon, [w:] Kompozytorzy polscy 1918-20oo, red. M. Podhajski, t. 2, Biogramy, Gdańsk-Warszawa 2005. 
Bilica K., Muzyka w obozie wedtug Szymona Laksa i innych, [w:] „Muzykalia” 2008, z. VI (Judaica 1).

Bristiger M., Wstęp, [w:] „Muzykalia” 2008, z. VI, (Judaica 1).

Chmielnik W., Terapeutyczne funkcje muzyki w sytuacji granicznej na przykładzie przeżyć obozu koncentracyjnego, „Sztuka Leczenia” 2010, nr 3-4.

Cykowiak Z., Kobieca orkiestra w oświęcimskim obozie, „Pro Memoria” 1996, nr 5.

Czech D., Kalendarz wydarzeń w KL Auschwitz, Oświęcim 1992.

Denscher B., Fritz Löhner, [w:] Lexikon verfolgter Musiker und Musikerinnen der NS-Zeit, [online] https://www.lexm.uni-hamburg.de/object/lexm_lexmperson_oooo2627 [dostęp: 31.03.2017].

Dunicz-Niwińska H., Drogi mojego życia. Wspomnienia skrzypaczki $z$ Birkenau, Oświęcim 2013.

Fackler G., „Des Lagers Stimme”. Musik im KZ. Alltag und Häftlingskultur in den Konzentrationslagern 1933 bis 1936, Bremen 2000.

Fackler G., Muzyka w obozach koncentracyjnych 1933-1945, tłum. S. Wieczorek, [w:] „Muzykalia” 2008, z. VI (Judaica 1).

Frankl V., Człowiek w poszukiwaniu sensu, tłum. A. Wolnicka, Warszawa 2015.

Godorowski K., Psychologia i psychopatologia hitlerowskich obozów koncentracyjnych, Warszawa 1985.

Goldensohn L., Rozmowy norymberskie. Oskarżeni i świadkowie w rozmowie z psychiatra, thum. A. Weseli-Ginter, Warszawa 2004.

Górniak J., Jeszcze o muzyce w Oświęcimiu, „Ruch Muzyczny” 1946, nr 2.

Grünberg-Rinkleff I., Grothe, Franz (Johannes August), [w:] Grove Music Online, [online] http://www.oxfordmusiconline.com/subscriber/article/grove/music/11836 [dostęp: 29.06.2014].

Helman Z., Laks Szymon, [w:] Encyklopedia Muzyczna PWM. Część biograficzna, t. 5 (KLE), red. E. Dziębowska, Kraków 1997.

Jarowiecki J., Przejawy życia kulturalnego w obozach koncentracyjnych, Kraków 1982.

Kaczorowska K., Adam Kopyciński, dyrygent o złotym sercu, „Gazeta Wrocławska" 12.02.2010, [online], http://www.gazetawroclawska. $\mathrm{pl} /$ artykul/220358,adam-kopycinski-dyrygent-o-zlotym-sercu,id ,t.html [dostęp: 4.01.2016].

Kalcher A., Leo Rostal, [w:] Lexikon verfolgter Musiker und Musikerinnen der NS-Zeit, [online] http://www.lexm.uni-hamburg.de/object /lexm_lexmperson_0ooo2268 [dostęp: 30.05.2016]. 
Knapp A., Holocaust, [w:] The New Grove Dictionary of Music and Musicians, red. S. Sadie, t. 13, New York 2001.

Kopyciński A., Orkiestra w oświęcimskim obozie koncentracyjnym, „Przegląd Lekarski” 1964, nr 1.

Kopyciński A., Ruch muzyczny za drutami Oświęcimia, „Ruch Muzyczny" 1945, nr 5.

Kopyciński A., Skład orkiestry obozowej w Oświęcimiu, „Przegląd Lekarski" 1966, nr 1.

Kulisiewicz A., Z zagadnień psychopatologii muzyki i pieśni w obozach hitlerowskich, „Przegląd Lekarski” 1974, nr 1.

Kupiec J., Cóż po nas zostanie...? Życie i twórczosśc więźnia obozu Auschwitz Mieczysława Kościelniaka, Oświęcim 2003.

Lachendro J., Orkiestry w KL Auschwitz, „Zeszyty Oświęcimskie” 27 (2012).

Laks A., O moim ojcu Szymonie Laksie i jego książce, „Muzykalia” 2008, z. VI (Judaica 1).

Laks Sz., Gry oświęcimskie, Londyn 1979.

Laks Sz., Coudy R., Duhamel G., Musiques d'un autre monde, Paris 1948. Lamb A., Berté, Heinrich [Harry], [w:] Grove Music Online, [online] http://www.oxfordmusiconline.com/subscriber/article/grove/music/02899 [dostęp: 29.06.2016].

Lamb A., Lincke, (Carl Emil) Paul, [w:] Grove Music Online, [online] http://www.oxfordmusiconline.com/subscriber/article/grove/music/16669 [dostęp: 29.06.2016].

Levi E., Graener, Paul, [w:] Grove Music Online, [online] http://www .oxfordmusiconline.com/subscriber/article/grove/music/11578 [dostęp: 29.06.2016].

Mrowiec M., Sztuka w piekle. Ocalały Chopin, „Dziennik Polski” 27.01.2012.

Naliwajek-Mazurek K., The Functions of Music within the Nazi System of Genocide in Occupied Poland, [w:] W. Klimczyk, A. Świerzowska, Music and Genocide, seria «Studies in Social Sciences, Philosophy and History of Ideas», t. 9, Frankfurt am Main 2015.

Auschwitz. Nazistowski obóz śmierci, red. F. Piper, T. Świebocka, Oświęcim 2004.

Potter P.M., Die deutscheste der Künste. Musikwissenschaft und Gesellschaft von der Weimarer Republik bis zum Ende des Dritten Reichs, Stuttgart 2000. 
Quignard P., Nienawiść do muzyki, tłum. E. Wieleżyńska, „Literatura na Świecie" 2004, nr 1-2.

Schäffer B., Szymon Laks [w:] tenże, Almach polskich kompozytorów współczesnych oraz rzut oka na ich twórczość, Kraków 1956.

Setkiewicz P., Krematoria i komory gazowe Auschwitz, Oświęcim 2010.

Setkiewicz P., Z dziejów obozów IG Farben Werk Auschwitz 1941-1945, Oświęcim 2006.

Shirley G., Music in the Holocaust. Confronting Life in the Nazi Ghettos and Camps, New York 2006.

Shuldman K., Jazz Survivor. The Story of Louis Bannet, Horn Player of Auschwitz, London 2005.

Siciński A., Pieśn pomogła przetrwać. W 25. rocznicę oswobodzenia Oświęcimia, „Dziennik Ludowy” 1969, nr 22, [kopia w:] Archiwum PMA-B, Zespół Oświadczenia, t. 72, k. 182.

Sieradzka A., Sztuka w KL Auschwitz, Oświęcim 2016, [online] http:// lekcja.auschwitz.org/pl_18_sztuka/ [dostęp 20.10.2016].

Stachura A., Motyw więźnia w twórczości artystycznej Mieczysława Kościelniaka, Jerzego Potrzebowskiego i Mariana Kołodzieja - więźniów KL Auschwitz, praca magisterska, Instytut Historii Sztuki Uniwersytetu Jagiellońskiego, Kraków 2016.

Szczepański I., Häftlingskapelle, Warszawa 1990.

Tuchowski A., Nacjonalizm, szowinizm, rasizm a europejska refleksja o muzyce i twórczość kompozytorska okresu międzywojennego, Wrocław 2015.

Würz A., Lincke, Paul, [w:] Deutsche Biographie, [online] https://www .deutsche-biographie.de/ppn118573071.html\#ndbcontent [dostęp: 31.03.2017].

Zduniak M., Kopyciński Adam, [w:] Encyklopedia Muzyczna PWM. Część biograficzna, red. E. Dziębowska, t. 5 (KLE), Kraków 1997.

\section{Abstract}

\section{Musical sources survived in the Collection of the Auschwitz- -Birkenau State Museum}

The article presents the conclusion of the research conducted by the author in the collection of the State Museum of Auschwitz-Birkenau, former German Nazi concentration and extermination camp. The 
sources are fully featured and described for the first time. The article focuses on showing a complicated post-war history of the camp items connected with music (musical instruments, printings, manuscripts, handwritten copies of instrumental books), which are auxiliary sources to reconstruct the repertoire of chapels in KL Auschwitz-Birkenau. The main aim of the article is to also discuss the preserved repertoire. In the last chapter, the author presents a short characteristics of original works composed by musicians and composers in slavery with a short analysis of all of them. Presented musical printings are a reflection of tastes of the German public in the 1930 s as well as an example of ridiculous anthropological establishments of Nazi music scientists and no ability to implement it on listeners practice. In addition, the work contains annexes: musical instruments, original works composed during camp existence, and musical printings - a list of music materials which survived in the collection of the Auschwitz-Birkenau State Museum.

\section{Keywords}

KL Auschwitz-Birkenau, musical sources, Holocaust Music, Music and Politics, Auschwitz-Birkenau State Museum. 